\title{
RESEARCH FOUNDATION YEAR IN REVIEW 2014
}

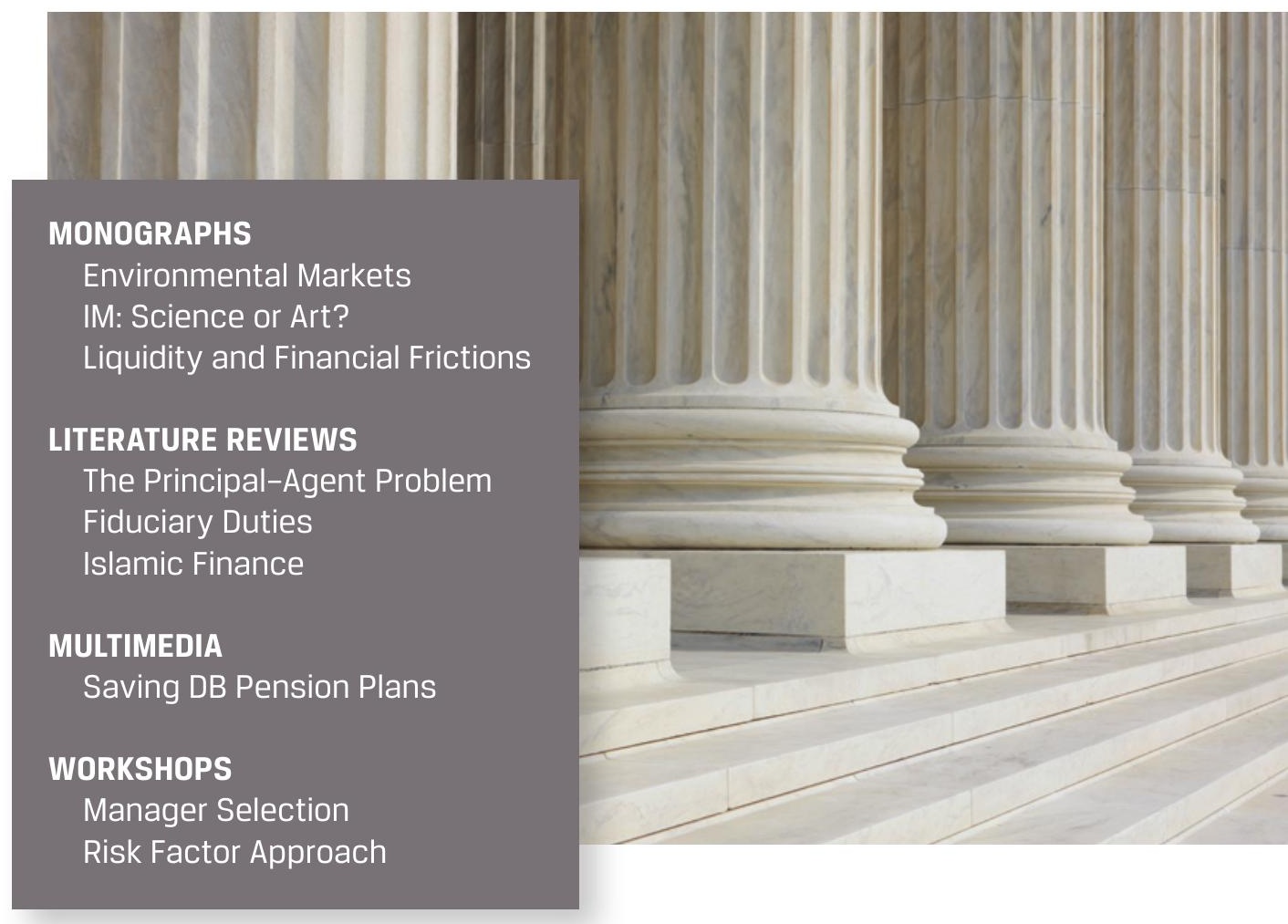




\section{Named Endowments}

The CFA Institute Research Foundation acknowledges with sincere gratitude the generous contributions of the Named Endowment participants listed below.

Gifts of at least US\$100,000 qualify donors for membership in the Named Endowment category, which recognizes in perpetuity the commitment toward unbiased, practitioner-oriented, relevant research that these firms and individuals have expressed through their generous support of the CFA Institute Research Foundation.

Ameritech

Anonymous

Robert D. Arnott

Theodore R. Aronson, CFA

Asahi Mutual Life

Batterymarch Financial Management

Boston Company

Boston Partners Asset Management, L.P.

Gary P. Brinson, CFA

Brinson Partners, Inc.

Capital Group International, Inc.

Concord Capital Management

Dai-Ichi Life Company

Daiwa Securities

Mr. and Mrs. Jeffrey Diermeier

Gifford Fong Associates

John A. Gunn, CFA

Investment Counsel Association

of America, Inc.

Jacobs Levy Equity Management

Jon L. Hagler Foundation

Long-Term Credit Bank of Japan, Ltd.

Lynch, Jones \& Ryan

Meiji Mutual Life Insurance Company
Miller Anderson \& Sherrerd, LLP

John B. Neff, CFA

Nikko Securities Co., Ltd.

Nippon Life Insurance Company of Japan

Nomura Securities Co., Ltd.

Payden \& Rygel

Provident National Bank

Frank K. Reilly, CFA

Salomon Brothers

Sassoon Holdings Pte. Ltd.

Scudder Stevens \& Clark

Security Analysts Association of Japan

Shaw Data Securities, Inc.

Sit Investment Associates, Inc.

Standish, Ayer \& Wood, Inc.

State Farm Insurance Company

Sumitomo Life America, Inc.

Templeton Investment Counsel Inc.

Frank Trainer

Travelers Insurance Co.

T. Rowe Price Associates, Inc.

USF\&G Companies

Yamaichi Securities Co., Ltd.

\section{Senior Research Fellows}

Financial Services Analyst Association

For more on upcoming Research Foundation

publications and webcasts, please visit

www.cfainstitute.org/learning/foundation/.

Research Foundation monographs

are online at www.cfapubs.org. 


\section{RESEARCH FOUNDATION YEAR IN REVIEW 2014}




\section{Statement of Purpose}

\section{The CFA Institute Research Foundation is a not-for-profit organization established to promote the development and dissemination of relevant research for investment practitioners worldwide.}

Neither the Research Foundation, CFA Institute, nor the publication's editorial staff is responsible for facts and opinions presented in this publication. This publication reflects the views of the author(s) and does not represent the official views of the CFA Institute Research Foundation.

The CFA Institute Research Foundation and the Research Foundation logo are trademarks owned by The CFA Institute Research Foundation. $\mathrm{CFA}^{\circledR}$, Chartered Financial Analyst ${ }^{\circledR}$, AIMR-PPS ${ }^{\circledR}$, and GIPS ${ }^{\circledR}$ are just a few of the trademarks owned by CFA Institute. To view a list of CFA Institute trademarks and the Guide for the Use of CFA Institute Marks, please visit our website at www.cfainstitute.org.

\section{(C) 2015 The CFA Institute Research Foundation}

All rights reserved. No part of this publication may be reproduced, stored in a retrieval system, or transmitted, in any form or by any means, electronic, mechanical, photocopying, recording, or otherwise, without the prior written permission of the copyright holder.

This publication is designed to provide accurate and authoritative information in regard to the subject matter covered. It is sold with the understanding that the publisher is not engaged in rendering legal, accounting, or other professional service. If legal advice or other expert assistance is required, the services of a competent professional should be sought.

Cover Image Photo Credit: @iStock.com/Veni

ISBN 978-1-934667-87-3

22 May 2015

Editorial Staff

Elizabeth Collins

Editor

Maryann Dupes

Director, Editorial Services
Cindy Maisannes

Manager, Publications Production

Mike Dean

Publishing Technology Specialist 


\section{Contents}

\section{The Year in Review}

Message from the Chair ................................................................... 1

Executive Director's Report ................................................................ 2

Research Director's Report ................................................................. 4

\section{Monograph Summaries}

Environmental Markets: A New Asset Class.

by Richard L. Sandor, Nathan J. Clark, Murali Kanakasabai, and Rafael L. Marques

Investment Management: A Science to Teach or an Art to Learn?

by Frank J. Fabozzi, CFA, Sergio M. Focardi, and Caroline Jonas

The New Economics of Liquidity and Financial Frictions

by David Adler

\section{Literature Review Summaries}

The Principal-Agent Problem in Finance

by Sunit N. Shah

Investment Professionals and Fiduciary Duties

by Marianne M. Jennings

Islamic Finance: Ethics, Concepts, Practice

by Usman Hayat, CFA, and Adeel Malik, PhD

\section{Multimedia Summaries}

"Saving DB Pension Plans: What It Will Take, and Why" with

M. Barton Waring (webcast)

by Laurence B. Siegel

\section{Workshop for the Practitioner Summaries}

Manager Selection

by Scott D. Stewart, CFA

Asset Allocation with Macroeconomic Foundations: The Risk

Factor Approach.

by Vasant Naik and Sébastien Page, CFA 
VI. Vertin Award

James R. Vertin Award ....................................................................... 65

VII. Research Foundation Leadership Circle................................... 67

VIII. Recent Publications from the Research

Foundation Archive ............................................................. 68 


\section{Message from the Chair}

As chair of the board of trustees of the CFA Institute Research Foundation, I would like to thank you for your interest in and support of the Research Foundation. It is because of you that we are able to advance understanding of the investment markets.

Established in 1965 and endowed by generous contributions from a number of prominent investment professionals and organizations, the CFA Institute Research Foundation is governed by an all-volunteer board of trustees and supported by a small staff. Our mission is to provide relevant high-quality investment research to the global investment community. This worldwide audience reflects the diversity of the modern investment industry-security analysts, portfolio managers, traders, brokers, consultants, fund sponsors (staff as well as trustees), and academics. It includes CFA Institute members and nonmembers alike.

To address the needs of such a broad audience, Research Foundation (RF) authors - practitioners and academics - are committed to producing investment research that is oriented to the practical application of investment finance. The research topics cover all fields relevant to investment professionals, and although that coverage may involve topical investment issues, RF research is meant to distinguish itself not by its timeliness but, rather, by its timelessness.

The majority of our research is published in book form, but we also produce literature reviews, webinars, occasional papers, and seminars on investment issues of particular interest. Notably, the Research Foundation hosts a workshop that is held just prior to the start of the CFA Institute annual conference. All RF materials are distributed online for free; the hard-copy versions are offered at a low price.

I hope you enjoy this issue of the Research Foundation Year in Review. I urge you to explore the impressive body of research that the Research Foundation has produced over the years. We welcome your comments and suggestions on how best to expand and distribute that work. We also look forward to celebrating the Research Foundation's 50th anniversary next year and launching a new line of research that features shorter treatments of content.

JT Grier, CFA

Chair

The CFA Institute Research Foundation 


\section{Executive Director's Report}

The CFA Institute Research Foundation is delighted to present the 2014 edition of the Research Foundation Year in Review. In this book, you will find time-saving summaries of our practitioner-focused research, which includes topics on environmental markets, challenges to common investment management tenets, liquidity and financial frictions, the principal-agent problem, ethics, and Islamic finance.

\section{Looking Back: 2014}

In addition to our published works, the Research Foundation (RF) held the 13th annual Research for the Practitioner Workshop featuring presentations on manager selection by RF author Scott Stewart and factor analysis by future RF authors Sébastien Page, CFA, and Vasant Naik. Also, Frank Reilly, CFA, and Fred Speece, CFA, were recognized for their outstanding contributions to the RF by being inducted into the Leadership Circle. They joined previous members Gary Brinson, CFA; George Noyes, CFA; Wally Stern, CFA; and Jim Vertin, CFA.

The RF Twitter presence (@CFAResearchFndn) expanded in 2014 to more than 8,100 followers reading more than 1,900 tweets. Please make sure that you follow the Research Foundation on Twitter so you can view the interesting content quotes that are frequently posted.

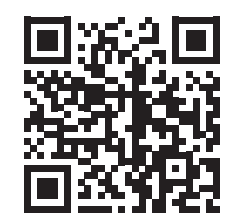

Partnerships between the Research Foundation and societies continued in 2014 as CFA Society Los Angeles hosted our spring board meeting, which featured a multimedia presentation on saving private pension plans by M. Barton Waring. Book donations to societies exceeded 50,000 copies for the year, and a new "Instant Lecture Kit" on A Primer for Investment Trustees was made available for society events and outreach. For the third year, the Research Foundation Society Award was granted to societies for their 
excellence in using RF content in events and outreach efforts. Year 2014 winners were as follows:

- CFA China

- CFA Society San Francisco

- Indian Association of Investment Professionals

- CFA Society Philadelphia (Encouragement Award)

The Research Foundation was once again pleased to have content highlighted by the CFA Institute Future of Finance project, and we look forward to working closely with this group in the future. We are also delighted to be contributing content from our upcoming book on trading to future CFA Program exam curricula.

As for the future, the Research Foundation is looking forward to its 50th anniversary in 2015 and is launching new short publications of global and regional interest to round out the user's experience of our content. Please join me in thanking CFA Institute, the RF Board of Trustees, our more than 7,000 donors, and the societies, volunteers, universities, and others who make the CFA Institute Research Foundation possible.

Bud Haslett, CFA

Executive Director

The CFA Institute Research Foundation 


\section{Research Director's Report}

The CFA Institute Research Foundation published three monographs and three literature reviews in 2014. We also initiated a new publication series consisting of shorter papers from the Asia-Pacific, EMEA (Europe, Middle East, and Africa), and Latin America regions, the first of which will be released in 2015.

\section{Monographs}

Richard L. Sandor, Nathan J. Clark, Murali Kanakasabai, and Rafael L. Marques, Environmental Markets: A New Asset Class. The tremendous improvement in environmental quality achieved in the United States since the passage of the Clean Air Act and the Clean Water Act in 1970 and 1972, respectively, has been mirrored by efforts in other countries to pursue similar goals. Based on theories of incentives and optimal resource allocation developed by the Nobel Prize-winning economist Ronald Coase, among others, cap and trade and other market solutions to environmental problems have been shown to be superior to command-and-control solutions. In Environmental Markets, Richard Sandor and his coauthors describe the universe of new investable securities created by cap and trade and similar legislation in various markets around the world.

"The eight chapters of this book," the authors write in their summary, "cover three broad asset classes: air and water, catastrophe and weather risk, and sustainability." The authors also show how environmental asset classes are being incorporated into more conventional commodity, fixed-income, and equity instruments. Chapters include a recounting of the successful elimination of acid rain through market mechanisms in the 1980s; a survey of greenhouse gas pollutants (thought to cause global warming) and the programs being implemented —or that could be implemented — to limit such pollution; and a detailed examination of water markets with a focus on such waterdeprived countries as Australia and India.

In many cases, these new environmental asset classes have not performed as investors hoped. This result does not mean there was a flaw in the product design but instead reflects changing market conditions, including the global financial crisis of 2007-2009, which helped remediate environmental damage through diminished industrial production. Since that time, we have also seen a dramatic commodity price cycle (up, then down), and this too has had an effect on the prices of environmental assets and liabilities. Investors should be 
mindful of these medium-term trends, but if the global environmental situation is going to continue to improve-as it already has in some respects-or at least stop deteriorating, then the market mechanisms represented by the new asset class of environmental securities will increase in importance.

Frank J. Fabozzi, CFA, Sergio M. Focardi, and Caroline Jonas, Investment Management: A Science to Teach or an Art to Learn? What should finance professors teach their MBA students? The answer to this question depends not only on what students need and want to learn but also on the state of financial theory and on the balance between teaching established concepts and exposing students to unresolved controversies. The authors use a survey approach, interviewing professors, employers, and others in Europe and North America, to address these issues.

In their summary, the authors note, "In the aftermath of the 2007-09 financial crisis, mainstream finance theory was criticized for having failed to either prevent or forecast the market crash. . . . This crash is particularly interesting in that finance theory, not simply the practices of the financial services industry, has been directly blamed." Did the efficient market hypothesis, modern portfolio theory, and the CAPM (capital asset pricing model) cause the crisis? It seems unlikely, considering that these theories have been around for a half century or more, but some authors have drawn a logical line between the widespread adoption of these concepts and the asset price bubble that burst and became the crash of 2008. The authors express some sympathy with this concept and explore ways that the teaching of finance can be improved.

The monograph distinguishes between art and science as ways of thinking about finance and investment management. The authors, noting that much of economics is mathematical, ask, "Do we have a science to teach?" and conclude that art is a better metaphor than science for much of what economics has to offer. They argue, "Economics and finance have as their subject a human artifact - the economy or the markets—not the laws of nature."

In their conclusion, the authors note that "any educational program is a compromise between time constraints and a potentially long series of topics to cover." They recommend increasing the attention given to

- macroeconomics, including a historical perspective on macroeconomics;

- the history of financial markets and economic history;

- behavioral finance;

- statistics beyond the use of the normal distribution;

- risk management; and

- ethics. 
We would remind readers that almost every college student is exposed to the idea, promoted by the philosopher and Harvard University Professor George Santayana early in the last century, that those who do not know history are condemned to repeat it. This is true in general but even truer in financial markets, which are subject to the same behavioral biases, bubbles, and crashes that plagued them hundreds of years ago.

\section{David Adler, The New Economics of Liquidity and Financial}

Frictions. The crash of 2007-2009 had many causes, but the primary cause was the inability of financial institutions to quickly sell securities they needed to sell in order to remain solvent. Yet much of macroeconomic theory says that can't happen. Theories often assume that investors can transact when they want to, without taking into account illiquidity and other financial frictions. Although such theories were developed for a reason-to simplify economic problems and make them more understandable and mathematically tractable-they often fail to explain and predict real-world phenomena.

In The Nerw Economics of Liquidity and Financial Frictions, Adler summarizes advances in financial and macroeconomic theory stimulated by the crash and its aftermath. He writes, "Though practitioners and the public may be astonished to learn it, mainstream macroeconomic models lack a financial sector. There are no banks. Moreover, these models formally rule out catastrophic outcomes for the economy. . . . The book explores the intellectual origins of this strange modeling pathway." The idea behind the pathway is that money and finance are a "veil" that, to some degree, obscures the real economic activity that is financed. Yet, in the United States, finance amounts to $8 \%$ of GDP and affects all of it. Moreover, financial crises have a much more profound and long-lasting impact on the real economy than other kinds of crises, so it is important to prevent them.

The author explains that the newest macro models do contain a financial sector. Moreover, they contain an amplification mechanism by which losses lead to larger losses in an expanded universe of assets-a spiraling pattern that we observe repeatedly in the history of financial crises.

Adler's monograph then turns to international concerns. He notes that, surprisingly, "free capital flows can be very damaging, an insight at odds with the prevailing policy and theory orthodoxy of the pre-crash world. Capital flows and the frictions or 'externalities' they create also explain a great deal about the boom and busts of the eurozone peripheral countries."

Asset pricing models, such as the CAPM, have also been affected by advances related to liquidity. The liquidity-adjusted CAPM, or L-CAPM, introduced by Viral Acharya and Lasse Pedersen in 2005, posits that expected 
returns on assets vary according to their liquidity, a finding that is not in the original CAPM. Adler writes, "Assets that are more vulnerable to liquidity shocks should offer higher expected returns given their riskiness. However, operationalizing the L-CAPM is far from straightforward."

Finally, the monograph addresses "macroprudential" regulation, a relatively new concept. Macroprudential regulation attempts to protect the financial system, not just the particular financial institution being regulated. There is a great deal of controversy about how to achieve this goal.

\section{Literature Reviews}

Sunit N. Shah, "The Principal-Agent Problem in Finance." The principal-agent problem is one of the central dilemmas of economics. In order for large, complex economies to function, principals (business owners, shareholders) must delegate authority to agents (executives and other employees). Without very careful contracting and policing of behavior, agents may act in their own interest and against that of owners.

This problem is especially prevalent in finance, the field covered by Shah's literature review. He adopts a historical view, starting with Ronald Coase's 1937 article "The Nature of the Firm" and progressing to the research of Jensen and Meckling, which, in 1976, helped launch the "shareholder value" movement to align executive and investor incentives.

Shah then focuses on two categories within the financial system that have attracted the attention of modern researchers: (1) asset management and (2) banking and related activities. Shah's analysis of the former begins with compensation structures. For example, because investors focus on short-term performance, so do managers seeking to maximize their fee revenue. This behavior harms the long-term interests of investors. Literature addressing ways of reducing this conflict is discussed.

The narrative then shifts to the banking industry, using the financial crisis of 2008 as a backdrop for the discussion. The banking industry contains many principal-agent problems across a variety of players, including bank management, traders, and rating agencies. Shah also examines the role of the government in both the crisis and the aftermath.

Principal-agent problems can never be completely resolved, but steps can be taken to reduce them. Investors, for their part, should be mindful of fees and other costs and should not chase recent past performance. 
Marianne M. Jennings, "Investment Professionals and Fiduciary Duties." Ethics are a primary concern of CFA Institute and the CFA Institute Research Foundation. In pursuit of this theme, we asked Jennings, a law professor emeritus at the University of Arizona, to review the literature on the fiduciary duties of investment professionals.

Investment advisers are unambiguously fiduciaries: They manage other people's money for a fee and are legally bound to act in the exclusive interest of the customer. Brokers are not typically fiduciaries; they are market makers, like a store owner or car dealer, and are presumed to act in their own interest while obeying laws regarding fairness and transparency. A difficulty arises when the line between investment adviser and broker is blurred. Most large brokerage firms also have investment advisory practices, and in some cases, those practices are the firm's primary profit source.

Jennings reviews the history of legislation, regulation, and self-regulation of each of these types of institutions. She sets forth a structure called the "regulatory cycle," in which poor outcomes lead the public to demand regulation; the industry then either pushes back, tries to self-regulate, or both. Finally, Jennings writes, the pendulum "moves toward regulation despite issues with cost and in defiance of information and research that demonstrates that the regulation will not be effective." She indicates that we are currently experiencing the last phase of the cycle.

Suggesting that the trend may be to impose a fiduciary obligation on brokers, the author then weighs the pros and cons of such a move, including the cost to society of limiting the market maker function.

Usman Hayat, CFA, and Adeel Malik, PhD, “Islamic Finance: Ethics, Concepts, Practice." Islamic finance, a rapidly growing field, is the practice of finance consistent with the avoidance of riba (interest) and excessive gharar (dealing in risk), as required by some branches of Islam. Hayat and Malik review the literature on Islamic finance, including literature that questions whether Islamic finance is functionally different from mainstream finance or just appears to be different.

The literature review is divided into 10 sections. The first two sections introduce basic concepts, including the idea that financial transactions should be consistent with economic justice, the avoidance of excess, and the requirement to be charitable. The third explains the concept of Shari'a, or Islamic law. The fourth, introducing the practice of Islamic finance, explains how contracts and promises are made to be Shari'a compliant. Some important financial instruments, including sukuk (bonds that avoid the explicit payment of interest) and takaful (Islamic insurance), are explained. 
The fifth section discusses how Islamic financial practices conform (or fail to conform) to legal and regulatory requirements around the world. The sixth section covers ethical, environmental, and governance issues. In the seventh section, the authors review the political and historical context for Islamic finance in the major countries in which it is practiced.

The eighth section addresses the question of whether Islamic finance differs or just appears to differ from conventional finance. This question is important because substantial resources are going into the development and promotion of financial instruments and practices designed to appeal to Muslims and to be permissible in Islamic countries; some economists are concerned that this effort is not accomplishing much of substance. The remaining sections state the authors' conclusions and provide an annotated bibliography.

Laurence B. Siegel

Gary P. Brinson Director of Research The CFA Institute Research Foundation 


\title{
Environmental Markets: A New Asset Class (a summary)
}

\author{
Richard L. Sandor, Nathan J. Clark, Murali Kanakasabai, and \\ Rafael L. Marques \\ Published 2014 by the CFA Institute Research Foundation \\ Summary prepared by Richard L. Sandor, Nathan J. Clark, \\ Murali Kanakasabai, and Rafael L. Marques
}

Population growth, industrialization, and urbanization in the past 200 years have resulted in local, national, and global pollution of our environment. Fossil-fuel combustion has resulted in rising levels of pollutants that cause smog, acid rain, and climate changes. Entire populations are faced with inadequate access to clean air and water, including China, India, Africa, and large areas elsewhere in the world.

The lack of ownership of air and water is the cause of the problem. The profit maximization model for a firm takes into account only the direct costs incurred by the firm, not the spillover costs, such as the negative repercussions associated with the pollution of air and water. Therefore, more goods and services are produced than would be if pollution were either controlled by fiat or internally priced (a condition in which the social, or external, cost of the pollution is figured into the decision about how much of the good or service to produce). ${ }^{1}$

These spillover costs, called "negative externalities," can be dealt with by mandating limits on pollutants (i.e., a cap) or requiring specific modifications in the production of goods and services. Spillover costs or benefits can also be mitigated by taxes and/or subsidies designed to drive down the level of pollution. In addition, externalities can be mitigated when public or private entities create a limited number of pollution or use rights corresponding to the environmentally acceptable cap on the pollutant. These property rights, called "allowances," can be purchased by companies for the purpose of compliance with environmental laws if they exceed their individual caps. Companies that reduce emissions in excess of their targeted caps can sell their allowances. The creation of a limited number (a cap) of property rights and their transferability (trade) has come to be known as "cap-and-trade." The transferability of allowances results in the market putting a price on the right to pollute. The price discovery allows

\footnotetext{
${ }^{1}$ The total, or social, cost of a good is internal, or ordinary, cost plus the external cost (e.g., pollution) of the good. If the external cost is a positive number, taking it into account makes the good more expensive. All other things being equal, if a good becomes more expensive, the quantity demanded will be lower, so the "right" amount to produce will also be lower.
} 
companies flexibility to choose an efficient way to reduce pollution. When the price is higher than the technology required to reduce or eliminate the pollution, companies will install the technology. If the opposite is the case, they will buy allowances. The price signals and flexibility enabled by a cap-and-trade program result in a least-cost solution to environmental problems.

The role of markets in reducing pollution and environmental degradation is not widely understood. Markets, when designed properly, can be a powerful agent for social and environmental transformation. These markets also act as economic drivers, generating jobs and improving the overall quality of life while acting as catalysts for innovation.

Early program outcomes, such as the phasing out of leaded gasoline and the virtual elimination of acid rain, led to widespread adoption of capand-trade throughout the world. The result has been creation of a new asset class - the environment - to join the traditional asset classes of stocks, bonds, real estate, foreign exchange, and tangible commodities.

Environmental asset classes are not a hope for tomorrow but a reality today. This new asset category promises to grow dramatically. Examples of environmental assets are rights to emit local and regional pollutants, such as sulfur dioxide and nitrogen oxide; rights to emit global pollutants, such as carbon dioxide; renewable energy credits; water quality and quantity rights; catastrophe and weather risk; and indices of sustainable corporate equities. This new asset class is the manifestation in securities and commodities markets of an emerging field of endeavor called "environmental finance." Environmental finance is the art and science of using economic incentives, financial tools, and market mechanisms to achieve desired environmental outcomes. ${ }^{2}$

This book is born out of economic theory and practical experience. Its purpose is to introduce this new asset class to financial analysts, investors, and corporations. It is of interest to these readers because it allows them to maximize revenues, reduce costs, and manage risks while promoting environmental and social benefits. Here is a new way to "do well and to do good."

From a corporate standpoint, businesses today have to be cognizant of, and prepare for, new kinds of corporate risks, including those arising from environmental problems and resource scarcity. These environmental risks include those related to production inputs (e.g., clean water for a beverage company), by-products of production (e.g., wastewater from chemical processing), and corporate social responsibility.

In addition, for companies to be competitive, their executives must be aware of opportunities that environmental markets have to offer.

${ }^{2}$ The term "environmental finance" was first adopted in an eponymous course offered by Richard L. Sandor at Columbia University in 1992. It helped ratify the academic underpinning of this growing new field. It has become widely used by other academic courses, industry publications, and conferences. 
Environmental asset classes allow businesses to pursue major new opportunities while simultaneously achieving their energy and environmental goals.

Similarly, financial analysts need to understand emerging environmental asset classes to evaluate companies on the basis of their environmental performance, exposure to environmental risks, and response to environmental opportunities. Portfolio managers may also want to incorporate these new asset classes in their portfolios.

The eight chapters of this book cover three broad asset classes: air and water, catastrophe and weather risk, and sustainability. The discussions also demonstrate how the environmental asset classes are being incorporated into commodities, fixed income, and equity instruments. The book concludes with some insights into the current state of this emerging asset class, some food for thought, and predictions about the future of environmental assets. We hope that the reader will walk away with a solid preliminary understanding of the promising and transformational new investment category of environmental assets.

The complete book can be found at http://www.cfapubs.org/toc/rf/2014/2014/1.

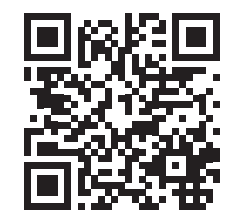

Use your smartphone to scan the $\mathrm{QR}$ code to go straight to the webpage. 


\title{
Investment Management: A Science to Teach or an Art to Learn? (a summary)
}

\author{
Frank J. Fabozzi, CFA, Sergio M. Focardi, and Caroline Jonas \\ Published 2014 by the CFA Institute Research Foundation \\ Summary prepared by Frank J. Fabozzi, CFA, Sergio M. \\ Focardi, and Caroline Jonas
}

In the aftermath of the 2007-09 financial crisis, mainstream finance theory was criticized for having failed to either prevent or forecast the market crash, which resulted in large losses for investors. Worse, the suggestion was made that the crash itself was the result of bad or poorly applied theory. Although markets have since recovered, surpassing precrisis levels as of the end of 2013, the investors enjoying the recovery are not always the same investors as those who suffered the losses. So, in many cases, the crash caused permanent impairment of wealth.

This crash is particularly interesting in that finance theory, not simply the practices of the financial services industry, has been directly blamed. This book explores current critiques of mainstream theory and discusses implications for the curricula of finance programs at business schools and universities. It is based on conversations with academics and practitioners in the industry and a review of the literature. ${ }^{1}$

Has mainstream finance theory-which many consider an idealization that does not take into account market reality—failed investors? Do we need to reconsider the theory and how it is taught?

\section{Finance Theory: Do We Have a Science to Teach?}

Many would argue that financial economics belongs not to the realm of empirical natural science but to the realm of the social sciences. Economics and finance have as their subject a human artifact-the economy or the markets-not the laws of nature. The artifact is context specific: It is not independent of social or political objectives. Hence, separating empirical laws from statements of principles is difficult.

Why is mainstream finance theory considered to be so unrealistic by so many? The answer is, not only because its main assumptions-efficient markets, rational expectations, the representative agent, and optimization,

\footnotetext{
${ }^{1}$ The full book contains a list of persons whose opinions (expressed either in interviews or in publicly available documents) are cited in the book. The many gracious human resources managers at asset management firms who helped us were promised anonymity and are not listed.
} 
which form the basis of general equilibrium theory-are unrealistic but also because the entire theoretical construct is not related to observable quantities. For example, a fundamental theoretical variable, price, is defined as the discounted present value of an infinite stream of future quantities that are not observable. The fact that finance theory makes impossible demands on the knowledge of economic agents is a crucial point that affects all mainstream general equilibrium theories.

In addition to this fundamental issue, the critique of mainstream finance theory can be summarized in three key points:

- First, no real agent has perfect knowledge of the future, not even in a probabilistic sense. Hence, the notion of rational expectations is unrealistic.

- Second, the representative agent is not a sound concept because one cannot aggregate utility functions and obtain a utility function with all the characteristics needed to justify equilibrium.

- Third, economies are rarely in a state of equilibrium. Joseph Stiglitz, professor of economics and University Professor at Columbia University and a corecipient of the 2001 Nobel Prize in Economics, has counted approximately 100 financial crises worldwide in the past 30 years.

Attempts have been made to address these problems within (or alongside) the existing theory. For example, although mainstream economists fail to recognize the existence of bubbles, some observers do attempt to explain market crashes, integrating into finance factors from outside classical finance theory. Specifically, the role of liquidity in the formation of sharp upward and downward market swings is now widely recognized, but will adding liquidity to mainstream finance theory be enough to achieve a complete understanding of markets? A longer list of what is needed to rethink finance theory, taking into consideration the real world, might also include leverage, bad behavior, bad incentives, and delegated management.

As for the role of human behavior in explaining large market swings, Robert Shiller, professor of economics at Yale University and corecipient of the 2013 Nobel Prize in Economics, explored how psychological factors drive stock markets in Irrational Exuberance. ${ }^{2}$ More recently, he has suggested that bubbles might best be referred to as speculative epidemics: Enthusiasm spreads from person to person like a contagion and, in the process, amplifies stories that might justify asset price increases. ${ }^{3}$

${ }^{2}$ Robert J. Shiller, Irrational Exuberance (Princeton, NJ: Princeton University Press, 2000; 2nd ed., 2005).

${ }^{3}$ Robert J. Shiller, “Bubbles Forever,” Project Syndicate (17 July 2013): http://www.projectsyndicate.org/print/the-never-ending-struggle-with-speculative-bubbles-by-robert-j--shiller. 
Andrew Lo, professor of finance at MIT's Sloan School of Management, developed what he calls the "adaptive market hypothesis." ${ }^{\prime 4} \mathrm{He}$ argues that by applying the principles of evolution (competition, adaptation, and natural selection) to financial interactions, it is possible to reconcile economic theories based on the efficient market hypothesis with behavioral economics.

Another way to improve finance theory would be to establish a link between financial markets and the real economy-a link that many find lacking in today's theory.

One might ask: Can the debate on the tenability of today's finance theory be resolved with the methods of empirical science? Will the debate remain at the level of dogma, as with the conflict between different views of political economics? Or will the debate remain at the epistemological level, centered on the question of what the cognitive value may be of a model that, in the best case, captures only some general features of the real economy and real markets?

Mainstream economic and finance theories make probabilistic predictions, but to test these predictions is difficult when samples are small and contain much noise. The late Fischer Black famously wrote, "Noise makes it very difficult to test either practical or academic theories about the way that financial or economic markets work. We are forced to act largely in the dark." ${ }^{5}$

Ultimately, the debate on general equilibrium models in economics and finance theory may be an empty one. Clearly, general equilibrium models are not empirically validated in terms of the characteristics and interactions of real agents. Given any asset-pricing model that does not admit arbitrage, however, we can always formulate an equivalent abstract general equilibrium model.

If prevailing theory indeed fails to represent the world as it is and has effectively proved to be of little practical use, can we consider our economic and finance theory to be hard science? Would it not be better to reinstate economics and finance as social sciences (albeit, given the inherently quantitative nature of the data, quantitative social sciences)? In this case, would we allot a reduced role to complex mathematics and modeling because of the problems with the theory behind the mathematics?

There are two arguments against considering economic and finance theory to be a mathematical science. The first is that economics and finance are dominated by single events that cannot be predicted or even described in mathematical terms. The second argument is that the dynamics of economic and financial phenomena are simply too complex to be captured by mathematical formulas - at least by today's mathematics. Perhaps the phenomena

${ }^{4}$ Andrew W. Lo, "The Adaptive Markets Hypothesis," Journal of Portfolio Management, vol. 30, no. 5 (30th Anniversary, 2004):15-29.

${ }^{5}$ Fischer Black, “Noise," Journal of Finance, vol. 41, no. 3 (July 1986), p. 529. 
are too complex to admit a parsimonious mathematical description. Forcing "mathematization" can actually impoverish, rather than enrich, knowledge.

The problem is not that economics is too mathematical; the problem is that the mathematics we use in economics is much too simple to capture the complexities of economic interrelationships. This situation calls for greater use of non-mathematical reasoning in managing assets. The likelihood is that economics and financial economics are only partially mathematical theories; they need to be complemented with less formal reasoning. For example, we might not have a lot of data on rare events, such as market crashes and depressions, but we can formulate reasonable scenarios that can, in turn, be mathematically represented.

Whereas some argue that economics and finance should be considered social sciences, others argue for a stricter adherence to the paradigm of empirical science. Again, the impact on the curriculum would not be negligible. The invention of high-performance computers marked a new epoch in the application of mathematics to science and ushered in the application of computational mathematics. Instead of being limited to closed-form solutions of differential equations, we could actually create, through simulation, structures of numbers or symbols that mimic the structure of reality. This advance greatly enlarged the areas of the practical applicability of mathematics. Nevertheless, many complex phenomena, such as the economy, still cannot be represented in detail by using mathematics. Various reasons account for this situation: chaos and sensitivity to initial conditions, objective complexity (the extent to which a phenomenon is close to randomness), and our ignorance of the laws. But these are moving targets.

If we follow the road of stricter adherence to the paradigm of empirical science, we can broadly distinguish three main subfields of scientific economics: (1) econometrics and signal processing applied to financial economics, (2) statistical mechanics applied to economics, and (3) complex system theory and network theory.

Econometrics is the oldest application of scientific principles to economics and finance. It is based on applying statistical methods-in particular, time-series analysis - to empirical data. The key problem is the amount of noise present in empirical finance data, which makes estimates highly uncertain. The diffusion of electronic transactions and the consequent availability of high-frequency and tick-by-tick data have enabled new methods of timeseries analysis borrowed from the field of signal processing. Econometrics and signal processing can be considered applications of the scientific method in restricted domains, such as trading and execution in investment management. These techniques are based on collecting data, constructing hypothetical models, and then testing the models. 
The application of statistical mechanics to financial economics is a relatively new field. Of the results obtained, perhaps the best known is the celebrated presence of fat tails in most economic data distributions. Fat tails of distributions imply that large events have a non-negligible probability of happening. Fat tails play a fundamental role in investment management, with important implications for the notions of diversification, risk-return optimization, and risk management.

Network theory is being used to model aggregation and contagion phenomena that may explain crashes. Some researchers argue that with the growing connectivity of economies and markets, aspiring risk managers would do well to study network theory to capture the system dynamics at work in a connected world.

\section{The Theory and Practice of Investment after the Crisis: Need for Change?}

Current mainstream finance theory is embodied in general equilibrium models that are idealized mathematical representations of markets populated by rational agents who have perfect knowledge of all possible contingencies now and into the infinite future and who optimize the utility derived from consumption and production. Agents are coordinated solely by price signals.

Even many of the theory's advocates acknowledge that these models are unrealistic (or simplistic) and require the consideration of additional "pieces." Among the additional pieces are the banking system, liquidity, employment and wages, instabilities arising from cascades of interactions, and crises.

The 2007-09 crisis has taught us some lessons. The lessons with relevance to investment management apply mostly to the following categories: diversification, optimization, the capital asset pricing model, the efficient market hypothesis, and risk measurement and risk management.

Diversification. Since the pioneering work of Harry Markowitz, diversification has been a fundamental concept in asset management and asset-pricing theories. ${ }^{6}$ From a statistical point of view, diversification is summarized in two mathematical facts: (1) The appropriate choice of weightsthat is, the proportion of funds invested in each asset-can reduce the variance of a portfolio while maintaining unchanged the portfolio's expected return, and (2) the variance of the portfolio that has the minimum possible variance is smaller than the variance of any of its components.

These properties are purely statistical facts and are, of course, undisputed. It is the effectiveness of diversification-at every level of aggregation - that has been questioned. Defenders of diversification argue that, although it might occasionally fail because of random fluctuations in market parameters,

${ }^{6}$ Harry Markowitz, "Portfolio Selection," Journal of Finance, vol. 7, no. 1 (March 1952):77-91. 
diversification remains a major component of investment decision making. Critics argue that diversification is ineffective in many economic states, such as when large market swings or crashes occur, because most expected returns in those states are negative. Market parameters change. The key question is how to optimize diversification strategies in markets characterized by changing parameters.

In addition, critics argue that diversification is a mathematical concept that is theoretically valid but whose application is difficult. Diversification requires the estimation - more precisely, a forecast - of the covariance matrix of returns. But the estimation of covariance matrices is subject to many uncertainties. In large portfolios in particular, empirical covariance matrices are very noisy because of the large number of entries.

Optimization. In the methodology of neoclassical finance, "efficient diversification of portfolios" is accomplished through mean-variance optimization (MVO). Broadly, optimization refers to a family of approaches to portfolio construction that include the use of alternative risk measures, such as tracking error and value at risk ( $\mathrm{VaR})$, the consideration of transaction costs, portfolio management constraints, and analyzing sensitivity to the estimates of expected returns and covariances.

As with diversification, the mathematics of MVO is not at issue. The question is, Does the mathematics of MVO correspond to the empirical reality of investments? The problem is whether or not we can find, empirically, a meaningful separation between diversifiable, unrewarded risk and non-diversifiable, rewarded risk. The defenders of MVO maintain that we can. Others observe, however, that MVO is of little use because it addresses only "benign" risksnamely, expected fluctuations in asset values as measured by standard deviation. It does not address systemic risks that can result in large losses.

The Capital Asset Pricing Model. The capital asset pricing model (CAPM) is an asset-pricing theory based on the assumption that all investors share the same rational expectations and use mean-variance optimization to choose portfolio weights. The key quantitative finding of the CAPM is that the expected excess return of each asset is proportional to the expected excess return of the market. The proportionality factor is the covariance between the returns of each asset and market returns.

In practice, however, the CAPM is often confused with a one-factor model. Many defenders of the CAPM view the poor performance of the model during the 2007-09 financial crisis as an expression of normal statistical fluctuations. Practitioners who consider the CAPM to be, in practice, a one-factor model observe that a one-factor model is a poor approximation of reality. 
The Efficient Market Hypothesis. The efficient market hypothesis $(\mathrm{EMH})$ is made up of two distinct hypotheses: (1) Asset prices have theoretical values (that is, an asset has a "fair price"), and (2) market prices coincide with theoretical prices. The link between the EMH and asset pricing is provided by the notion that the theoretical value of an asset is the present value of its future discounted cash flows. Markets are efficient if the price of each asset equals or comes close to the present value of its future discounted cash flows. But because we have no way to forecast cash flows into the distant future, some argue that the EMH is an empty idea.

The EMH is the concept that has raised perhaps the most debate after recent market crises, including the 2007-09 crisis. It is an academic hypothesis that markets are "efficient" in the sense that market prices are always equal to theoretical prices. But it seems to be at odds with the reality of a market that lost $57 \%$ of its value from its peak in October 2007 to its bottom in March 2009 and then bounced back to its precrash high within four years.

The twin hypotheses of asset pricing and the EMH are not verifiable.

Risk Measurement and Risk Management. Risk management, too, was in for criticism following the recent financial crisis. It is not the concept of risk management that is questioned, however, but our tools and what we measure. First, the adequacy of our risk measurements and models is questioned. For example, most asset management firms still use measurements based on the assumption of normality, such as the risk metric VaR. Second, the scope of risk management may be too narrow. In particular, the tools fail to take into consideration systemic risk-a key failure in light of the wide use of derivative products that can propagate risk in ways that are difficult to understand and control.

Mainstream theory maintains that the economy and markets are in a state of general equilibrium and that only large, unpredictable exogenous events can disturb this equilibrium. Attempts to explain crises that are not explained by mainstream theory have taken two approaches. One approach starts with the observation that economies and financial markets are unstable complex systems. Far from being self-correcting equilibrium systems, economies and financial markets have endogenous mechanisms that may lead to a crisis when many interacting units (e.g., financial institutions) form networks in which very large connected components occur. A high density of connections can lead to cascading effects. Researchers working in this field apply complex system theory to identify potentially dangerous thresholds of connectivity.

The other approach goes back to Hyman Minsky, who maintained in his financial instability hypothesis that crises are generated by an excess of money, which fuels speculation and causes asset price inflation, followed by 
debt deflation. ${ }^{7}$ Researchers attempting to model bubbles and crashes following Minsky's hypothesis are applying tools from nonlinear dynamics.

\section{Teaching Finance: Can We Do Better?}

Should the recent financial crisis, which contradicted so many central "truths" of modern economic and finance theory, change how we teach investment management? What should we be telling students about our theories and our models? Do we need to teach a new investment paradigm, as some have argued? What do we include in and what do we exclude from the curriculum of students whose objective is to manage other people's money? And has anything changed since the start of the 2007-09 financial crisis?

The overall perception of the academics and practitioners we surveyed is that not much has changed to date. Two reasons are given: First, not everyone is persuaded that changes are called for. Many academics believe that the current framework is solid and that we need only make minor adjustments. Second, some academics believe that throwing 40 years of research out of the curriculum straightaway is not so easy. These academics are trying to gradually rebalance their approach to teaching finance and the curriculum.

Given the widespread criticism of mainstream finance theory based on an idealization of markets, however, we ask: If our financial economics and finance theory are indeed of little practical use, in that they do not describe market reality, is it appropriate to teach the theory to students who, for the most part, are in school for practical purposes? And if the practical applicability of mainstream theory is so poor, why teach the difficult mathematics in which the ideas of general equilibrium, market efficiency, modern portfolio theory, and continuous-time asset pricing are cast?

Those in favor of keeping our theory argue that, although the theory is imperfect (it is still a work in progress), it is the way we teach the theory (too simplistic) that needs to change. Most (not all) sources we interviewed in our study agree that today's theory provides a useful framework for thinking about economic and finance problems but has limitations. Because today's finance theory has limitations, many suggest that it be taught less dogmatically, more pragmatically, than it is currently taught.

What specifically should we do in terms of changing the way we teach finance theory - in particular, the way we teach finance to students aspiring to be investment professionals?

Consider general equilibrium theory, which states that the economy and markets are in a state of general equilibrium, meaning that the market for every good and service clears at a price where the quantity supplied equals the

\footnotetext{
${ }^{7}$ See Hyman P. Minsky, Stabilizing an Unstable Economy (New Haven, CT: Yale University Press, 1986) and "The Financial Instability Hypothesis," Working Paper No. 74, Jerome Levy Economics Institute of Bard College (May 1992).
} 
quantity demanded; this equilibrium can be disturbed only by large unpredictable exogenous events. The recurrence of financial crises led David Romer at the University of California, Berkeley, to conclude, however, that financial shocks are more commonplace than exceptional. Some believe that because financial markets are essentially nonstationary and unstable, we are neither teaching the right concepts nor giving the appropriate tools to future investment managers.

For example, diversification is widely held to be a sound probabilistic concept, but the benefits of diversification may change as market states, correlations, or expected returns change. In the case of market corrections or crashes, even a well-diversified portfolio is not protected against large losses. Students are taught about diversification, but they are not taught what might be done when the correlations among markets grow and diversification does not work-or works less well than it has been working. Nor are students taught how to deal with chaos or non-normal distributions, which is another illustration of the fact that we are not preparing students to handle events outside the theory of general equilibrium. In teaching diversification, we would benefit students if we talked about structural breaks and estimation errors of the variance-covariance matrix and their implications for the composition of efficient portfolios and if we focused on how to reduce estimation error, account for fat-tail correlations, and perform extreme-event stress testing.

Another theory, the CAPM, is a flawed partial equilibrium theory, and the one-factor model is sloppy econometrics. Yet, despite the fact that the tenets of the CAPM have been invalidated in numerous empirical studies, the model is still widely taught as a theoretical framework for asset pricing. Should we continue to teach the CAPM?

The academic emphasis on asset-pricing models, which focus on precise asset pricing as opposed to pragmatic decision making, has also been questioned. The argument here is that asset pricing is an intellectual exercise; focusing on decision making forces one to think pragmatically and gives priority to forecasting and uncertainty.

Some practitioners and academics believe there is an overdependence on a theoretical framework that does not describe real markets. They seek empirical verification and are in search of a different type of theory, one that is more in line with the paradigm of the physical sciences and thus of more practical use. For example, Andrew Ang, professor of business at Columbia Business School, considers factor theory central to asset management. He believes that understanding factors is the key to understanding returns.

That the reality of markets should be the primary object of study is perhaps the key adjustment that needs to be made to both the theory and the teaching of finance.

Finally, risk measures commonly used in asset management, such as standard deviation and VaR, have come under criticism for their 
inadequacies - particularly because of their reliance on the assumption of a normal distribution. These commonly used measures are considered too narrow in scope because they are typically limited to a statistical measurement of market risk. The focus on market risk measurement is questioned: Most of the literature and especially investment texts have focused on equity markets and two-tailed risk, even though the largest collapses of the last two decades or so (the failure of Long-Term Capital Management and the subprime mortgage crisis) occurred in the fixed-income markets. In short, not enough attention is being paid to credit risk evaluation, collapse models, and cross-market contagion.

What about market crashes? The potential impact of a crisis on a portfolio can be enormous. Crises occur, but they do not find their place in mainstream finance's general equilibrium theory. Perhaps these events should be factored into the risk structure.

\section{What's Missing in the Curricula for Future Investment Professionals?}

We asked academics and practitioners what, in the wake of the most recent financial crisis, needs to be reinforced or (re)introduced in programs preparing students for jobs in investment management.

Clearly, to pack additional courses into the typical two-year MBA finance program would not be easy. Another problem in discussing the curriculum is the diversity of roles. Is there any common body of knowledge that should be shared among market participants and, therefore, reflected in the curriculum? Yet another problem is today's emphasis on theories and models not based on empirical evidence.

As for $\mathrm{PhD}$ programs in finance, the main concern is that too much time is allotted to mastering difficult mathematical methods at the expense of developing broad knowledge of economics and finance.

Clearly, any educational program is a compromise between time constraints and a potentially long series of topics to cover. Here is the list of subjects (in order of number of mentions) that our sources believe should be reinforced in or (re)introduced to the curriculum:

- macroeconomics, including a historical perspective on macroeconomics,

- the history of financial markets and economic history,

- behavioral finance,

- statistics beyond the use of the normal distribution,

- risk management, and

- ethics. 
The current interest in macroeconomics and its history is probably a reaction to the recent financial crisis, which (unduly) surprised so many academics and market participants. Despite its importance, macroeconomics—not any particular approach or ideology - is widely considered to be poorly covered in current curricula. Rather than the formalism and mathematics of the general equilibrium theory, or anomalies in capital markets, what would be beneficial to students is more exposure to macroeconomics and its related fields, such as interest rates, exchange rates, and inflation. Many of our sources believe that a mix of judgment and nonquantitative macro/markets analysis is required to identify regularities and patterns in events and to recognize regime shifts.

There are two other compelling reasons for reinforcing macroeconomics in the curriculum. First, in the end, the economy drives financial markets. A disconnect between economies and financial markets generally implies that financial profits are being created artificially, thus bringing about a situation of instability. Second, in the wake of the 2007-09 financial crisis and ensuing Great Recession, governments are playing a growing role in the economy and markets.

Another important subject frequently mentioned as missing from the curricula for future investment professionals is the history of finance and of financial markets. The 2007-09 financial crisis alerted many to the role of history as a measure and model of crises. Teaching the history of finance and of financial markets would give students a long-term perspective, allow them to learn from past crises, and provide illustrations of, for example, the effect of financial euphoria on markets. It would also provide a way of testing our conventional hypotheses.

In addition to history, learning from current affairs (in particular, with regard to the recent crisis) was singled out by our sources as an oft-neglected area.

The need to include more on behavioral finance in the curriculum for future investment professionals was also noted. Behavioral finance began to move into finance programs even before the 2002 Nobel Prize in Economics was awarded to the behavioral psychologist and economist Daniel Kahneman. The objective of behavioral finance is to improve our understanding of markets and our forecasts by attempting to explain market movements as the result of cognitive biases (deviations from so-called rational judgment) on the part of market participants. How do we teach behavioral finance? What do we expect to be able to do with it?

The increasing relevance of statistics, mathematics, and modeling in finance programs arises from the greater availability of market and economic data and low-cost computing power. The issue of teaching these subjects to future investment professionals has two sides: Some curricula put too much emphasis on statistics, mathematics, and modeling, so students risk losing the 
big macroeconomic picture; others do not teach enough statistics, mathematics, and modeling, so students receive insufficient training and are unable to work with large datasets, apply the appropriate modeling techniques, and interpret the results. Learning how to collect and evaluate data (skills not always taught by the school), as well as how to create models (if only with simple modeling methods), should be part of every finance student's formal education.

Finally, with respect to risk management, portfolio management is based on the notion of optimizing the risk-reward trade-off. Risk management, therefore, is at the heart of asset management. But although things have begun to change since the 2007-09 financial crisis, many believe that risk management is not sufficiently taught in most finance programs. Risk management entails more than risk-return optimization. First, as proposed by Benoit Mandelbrot more than 50 years ago, the notion of portfolio risk should be based on non-normal (as opposed to normal) distributions. ${ }^{8}$ Second, accounting is an important source of risk that deserves more attention in curricula than it has been receiving. Third, risk management is asset/ liability management, not asset management alone. The role of liabilities and the interaction between assets and liabilities are not well covered in business schools, except in the few insurance programs that exist. The "meta-risk" of model failure and systemic risk are other categories of risk that have been given little consideration in most risk management curricula.

\section{Landing a Job in Investment Management}

In the recruitment of recent graduates for jobs in investment management, the emphasis is now being placed on solid economic reasoning and understanding of the "big picture," including the global macro and (geo)political situations. The growing importance of good macroeconomic reasoning represents something of a change from recent years. Firms, including quantitative asset management firms, are now looking for economic reasoning skills and math in the same person. Moreover, they are apparently having difficulty finding that combination of attributes. From the point of view of business schools and universities preparing students (including PhDs) for jobs in investment management, this trend calls for a well-rounded curriculum that encompasses a broad spectrum of fundamental knowledge and quantitative skills.

One criticism of most current finance programs is that too little attention is paid to creativity and out-of-the-box thinking in developing students' ability to understand, to critique, and to find new angles to a problem. Students need to be exposed to various ideas and points of view in order to develop the mental flexibility that is required to think outside of established schemas. Many human resources managers find these qualities lacking in graduates

${ }^{8}$ Benoit Mandelbrot, "The Variation of Certain Speculative Prices," Journal of Business, vol. 36, no. 4 (October 1963):394-419. 
coming from traditional business schools that teach (often dogmatically) mainstream economic and finance theory.

In addition, many finance programs, especially mathematical finance programs, are criticized for putting too much emphasis on models. The criticism is that these programs are divorced from events in the real world and produce recruits who have an equation for everything but who lack broader knowledge.

According to human resources managers, although the school does count, recruitment is a question of the individual. Business school graduates with an MBA are typically "top picks" in the United States. The situation is different in Europe, where some report that they have seen negative added value in MBA hires. That is, the cost of recruits from these programs is high, and the value they add is not sufficient to cover the cost.

The complete book can be found at http://www.cfapubs.org/toc/rf/2014/2014/3.

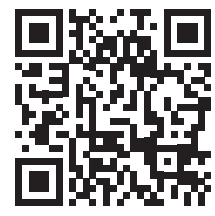

Use your smartphone to scan the $\mathrm{QR}$ code to go straight to the webpage. 


\section{The New Economics of Liquidity and Financial Frictions (a summary)}

\section{David Adler \\ Published 2014 by the CFA Institute Research Foundation Summary prepared by David Adler}

The financial crisis caused an intellectual crisis in economics. Not only were conventional models and risk metrics unable to anticipate the crash, but they also had trouble grappling with it and its consequences long after it occurred.

The New Economics of Liquidity and Financial Frictions is a book about a new branch of economics that has emerged since the crisis, though work on the subject began far earlier. This new field is largely a synthesis of macro and finance. A friction is an impediment, obstruction, or constraint that prevents markets and economies from working smoothly. A crippled financial sector and lack of liquidity are critically important frictions. The field's emphasis is on the frictions posed by both a credit boom and a credit bust. Frictions provide a new framework for viewing the economy.

The goal of the book is to convey to practitioners this modern economics, which in many ways is a radical departure from the older, frictionless approach still prevalent in economics textbooks and most of academia. It presents the many new models in this area, the intellectual history behind their development, and their strengths and limitations. But the insights offered by the new field are hardly just academic. This book provides a new understanding and approach to asset pricing, risk measurement and management, central banking policy, and the overall working of today's economy, including questions of financial stability. Importantly, this new field is also driving regulation, with key new systemic risk measures now enshrined in Basel III.

\section{Marrying Macro and Finance}

Though practitioners and the public may be astonished to learn it, mainstream macroeconomic models lack a financial sector. There are no banks. Moreover, these models formally rule out catastrophic outcomes for the economy. Hence, when the crisis occurred, central banks, to the degree they relied on the most advanced macro models of the day, known as dynamic stochastic general equilibrium (DSGE) models, lacked a road map for what was to come.

Chapter 1 explores the intellectual origins of this strange modeling pathway. There are both intellectual and practical justifications for these models' oversights. In the canonical theories of economics, finance is just a "veil" over 
real activity. Moreover, most of the models were developed in the post-World War II era in the United States-a time of great financial stability, when systemic financial crises were not a pressing concern.

The first chapter also profiles the work of early economists who took a different approach: Irving Fisher, John Maynard Keynes, and, more recently, Hyman Minsky. Newer macro models-including that of Bernanke, Gilchrist, and Gertler-formalize some of the insights of these older economists, most notably those of Irving Fisher.

The most cutting-edge macro models of today do include a financial sector. These models show how a small financial shock can be amplified into something much larger through the involvement of the financial sector. These crises involve negative feedback loops between the real economy and the financial sector and within the financial sector itself. The models shed light on why financial crises are uniquely damaging, more so than ordinary recessions and, in some senses, more so than a war.

Chapter 1 concludes with a description of the "financial cycle." This cycle consists of insidious, slow-moving credit booms and busts. The financial cycle is much less well-known to investors than the business cycle. However, it is now a main focus of macroeconomic research and central bank concern because peaks in the cycle are associated with subsequent financial crises.

\section{Financial Frictions in an International Context}

In Chapter 2, the book next considers how financial frictions apply in an international context. Here, the friction in question is surges in capital flows, as well as their cessation. Capital inflows into emerging economies can set off economic booms in these countries, culminating in a macroeconomic and exchange rate crisis. These booms and busts consist of positive and negative feedback loops in these countries involving capital flows, asset prices, and the exchange rate. One policy conclusion - at odds with mainstream thinking until very recently - is that capital controls on inflows are needed for macroprudential reasons.

This chapter presents new models of financial instability and amplification mechanisms for developing economies. These models, unlike older, frictionless international models, consider the impact of externalities caused by capital inflows. Such externalities can be corrected through effective use of capital flows. However, empirical literature has found that capital controls have in most instances proven to be "leaky," so other approaches are called for.

The book examines the crisis in the peripheral countries of the eurozone through this prism of financial frictions in an international context. The crisis in these countries can largely be explained by this new economics focused on capital flows and the booms and busts they set off. Conventional analyses of the eurozone crisis instead focus on other explanations, such as fiscal 
imbalances, the need for austerity or the damage caused by it, and the policies of the European Central Bank. In contrast, the book argues that the underlying problem in the peripheral countries is their lack of competitiveness stemming from the boom that preceded the bust. Capital inflows drove wages ahead of productivity. An internal devaluation could be a solution, albeit one that would be very hard to implement.

\section{Asset Pricing}

Chapter 3 offers fresh insights into asset pricing and presents several new asset pricing models. Though many of these models are still on the research frontier and are very stylized, their ideas can be used for portfolio design, both to guard against an unexpected liquidity crisis and as a way to increase returns.

Traditional asset pricing models, such as the capital asset pricing model (CAPM), ignore financial frictions: Markets are complete, there are no transaction costs, and investors face no leverage constraints. A handful of contemporary asset pricing models now include realistic frictions, such as lack of liquidity.

Liquidity has no single definition or measure in finance. Nonetheless, there is widespread evidence that lack of market liquidity, however defined, affects expected returns in two ways-as a transaction cost that investors must be compensated for and as a priced risk "factor." Assets whose prices decline when liquidity crises arise should offer higher expected returns because of this risk. These ideas about the importance of liquidity as a characteristic and as a risk factor-both of which affect expected returns- have been formalized in the liquidity CAPM, or L-CAPM, discussed in Chapter 3.

Liquidity and the higher expected returns from illiquid assets may explain a great deal about the unconventional success of the endowment model. Endowment portfolios tend to be highly illiquid. Chapter 3 looks at the role of illiquidity in endowment portfolio design and returns, as well as lessons for individual investors trying to replicate this approach.

Funding liquidity is another aspect of liquidity. It lacks a consensus definition but generally refers to the ability of financial intermediaries to satisfy their funding or short-term capital needs. Funding liquidity risk is an additional priced risk factor. It can also be a very useful economic indicator. Certain funding liquidity measures have some predictive power in terms of market performance. Chapter 3 discusses several measures in this area.

\section{Macroprudential Regulation and Systemic Risk}

Systemic risk and the related topic of macroprudential regulation are discussed in the penultimate chapter of the book. Both terms lack agreed-on definitions and measures. Macroprudential regulation is generally concerned with policies that strengthen the financial system as a whole, rather than just 
an individual institution. Systemic risk is the risk posed by threats to stability of the financial system.

Chapter 4 explains that there are actually two dimensions to systemic risk: (1) risks posed by the failure of a financial intermediary that is considered too big to fail, or too highly interconnected to fail, at a particular point in time and (2) risks that build up over time. This second category of systemic risk is essentially synonymous with the financial cycle described in Chapter 1 . There are many different measures of systemic risk. The standard measure for a buildup in systemic risk over time is the "credit-to-GDP gap" developed by the Bank for International Settlements. The chapter explains the theory behind these concepts as well as the actual calculations involved in the measures.

Regulators are closely following research developments related to systemic risk. Specific systemic risk measures are now embedded in Basel III and influence the setting of countercyclical capital buffers.

Chapter 4 concludes with a look at CFA Institute's initiatives related to systemic risk, including the work being done by the Systemic Risk Council, an independent project jointly created by CFA Institute and the Pew Charitable Trusts. Its advocacy efforts address regulatory and structural issues relating to systemic risk in the United States.

\section{Conclusion: Financial Frictions and the Path to Reform}

The final chapter looks back to highlight overlooked financial frictions that may have been central to the crisis. Chapter 5 also analyzes various theories as to why growth since the crisis has been so anemic and describes current debates among central bankers about what to do in response. It concludes with ways to ensure greater financial stability, as well as how the social science of economics itself could be improved on in terms of some of its practices, including a greater emphasis on financial frictions.

Financial economists were not just negligent in ignoring the risks posed by an unstable financial sector in theory. They ignored the changing nature of financial intermediaries in practice: There were extremely few academic research papers about the US shadow banking system. This system was larger than the traditional banking system but had unusual vulnerabilities. In particular, it lacked a lender of last resort that could provide a liquidity backstop in times of crisis. Hence, the shadow banking system was vulnerable to runs.

Chapter 5 looks at various theories as to which market experienced the first run during the crisis in the United States. The repo (repurchase agreement) market is the conventional suspect. However, recent evidence suggests that runs in asset-backed commercial paper were larger and occurred earlier than runs in repo. 
Interventions by the Federal Reserve were able to stop these runs. However, these interventions may have had unintended negative consequences: They may have sowed the seeds of further financial instability. Chapter 5 points to the importance of macroprudential considerations in monetary policy. Relying on regulation alone may not be enough to ensure financial stability.

There is little consensus about why growth in advanced economies has been so anemic since the crisis. Chapter 5 discusses various theories related to the "secular stagnation" hypothesis and ideas for what policymakers can do next.

The book concludes with a call to continue including realistic financial frictions in abstract economic models and analysis. The New Economics of Liquidity and Financial Frictions examines a field very much still in active development that is creating new theories and policies to ensure financial stability and improve economies' resilience to future financial crises.

The complete book can be found at http://www.cfapubs.org/toc/rf/2014/2014/4.

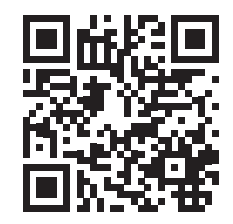

Use your smartphone to scan the $\mathrm{QR}$ code to go straight to the webpage. 


\section{The Principal-Agent Problem in Finance (a summary)}

\section{Sunit N. Shah \\ Published 2014 by the CFA Institute Research Foundation Summary prepared by Sunit N. Shah}

Despite its prominence in economics today, the study of incentives is relatively new. Included in this field is the study of the principal-agent relationship. The principal is one who, within predefined terms, assigns a task to an agent, who performs the task on the principal's behalf. If the agent's incentives are not aligned with those of the principal and the principal cannot monitor the agent's actions, the agent has both the motivation and the ability to act undetected against the principal's interests. This scenario is referred to as the "principal-agent problem."

Early in the history of economics, researchers focused primarily on the behavior of market participants on an aggregate level. Ronald Coase is widely credited with taking the analysis one level deeper in the 1930s with his examination of the firm. In the 1950s and 1960s, economists began to examine how differences in incentives among members of a given team cause the various members to act differently from each other, sparking the subdiscipline of economics known as "optimal contract theory."

At the same time, another set of economists, including Robert Wilson and Kenneth Arrow, were exploring the nature of risk sharing among groups of people with different preferences for risk. Such studies brought to light a set of difficulties that can occur when parties to a contract involving risk transfer alter their actions after the contract is agreed upon. This area of work came to be known as "agency theory."

These two lines of study share a common thread: Each party to a contract must recognize that the other parties may change their behavior after the contract has been struck. The key question is how to structure the contract to minimize potential problems. These two fields eventually merged, and from this union, the principal-agent model and the study of the principal-agent problem were born.

For the principal-agent relationship to be problematic, two ingredients are needed: conflicting incentives and private information. Without the former, the principal may simply leave the agent to his or her own devices; without the latter, the principal need only structure the contract to cover each realization of private information ex post. 
It is not surprising that the financial services industry finds itself rife with potential principal-agent problems. The interconnectedness of the industry has created a myriad of agency relationships in which monitoring is difficult, and many of these relationships involve risk transfer or risk sharing within groups. Consequently, ethical standards within the field must be high, lest the power of participants' own incentives drive them to act counter to their fiduciary duty to their clients.

Unfortunately, strong ethical standards have not been upheld. As several studies have shown, many participants in the finance industry who have witnessed wrongdoing do not report it and, worse yet, many would engage in illegal activity to get ahead if they were sure they would not be caught. These patterns exist even though other studies have shown that trust is the attribute that is most important to investors when hiring investment managers-even more important than an ability to achieve high returns.

Examining the literature that discusses such problems in two important areas of finance, asset management and the banking industry, is an important step in promoting the introspection needed to reevaluate the industry's practices.

\section{Compensation Structures in Asset Management}

Asset managers often receive two streams of revenue for their services. One, called a "management" fee, is a fixed percentage of the assets under management and is often justified by overhead expenses, such as payroll, rent, and infrastructure. The second revenue stream is referred to as the "performance" or "incentive" fee and is a predetermined percentage of the return the manager generates on the investor's assets.

On the one hand, because the manager does not pay the investor back for losses generated, the incentive fee is an option-like component of the management contract. The management fee, on the other hand, is an equity-like position in the fund because it grows commensurately with the assets. Consequently, the choice between the incentive fee and the management fee boils down to a choice between option compensation and equity compensation.

Much research has been done on these fee structures. Some of the research examines this topic in a static framework; that is, some studies use a one-period model without considering changes to the fund over time. Most of this subset of the research concludes that incentive fees do not have a high correlation with actual manager incentives and that the management fee component of the structure does a better job than the incentive fee of aligning a manager's motives with those of the investor.

Research examining this topic in a dynamic framework has incorporated the question of how capital flows react to fund performance over time. Such research finds that, although outperformance in a given period does benefit the 
manager through higher fees in that period, the larger benefit to the manager comes from the additional fees he or she will receive in future periods on the capital inflows that result from this outperformance. Furthermore, the potential for redemptions in periods of underperformance can cause managers to take on less risk than is optimal, with the result that higher incentive fees are often required to counter this effect by motivating managers to take on more risk.

To collapse risk and return into one metric, some investors evaluate managers based on the Sharpe ratio a manager has achieved historically, but research has cast doubt on the effectiveness of such a metric in promoting prudent manager behavior. If the manager has an incentive to maximize his or her Sharpe ratio, that manager may execute strategies that generate a small profit in almost all scenarios but lose an enormous sum in the remaining few. An example is pairing an out-of-the-money short call position with an out-of-the-money short put position. Although such an approach may maximize a manager's Sharpe ratio in some circumstances, it is unlikely to be in the investor's best interest.

\section{Investor Short-Termism}

The direct incentives in the field of asset management are generally governed by the manager's compensation structure, but investors themselves often indirectly provide managers with incentives to act counter to the investors' interests through a focus on short-term results. That investors tend to focus on the very recent past, a phenomenon known as "short-termism," is well documented. In fact, most of the literature considers this behavior as simply one aspect of human nature in investing. The behavior is grounded in several well-established psychological effects, such as recency and saliency, and studies have shown that such behavior not only exists but also is increasing in magnitude over time. This tendency on the part of investors may force asset managers to manage for the short term, thereby causing them to neglect the best interests of those very investors.

The bulk of the research on investor short-termism has examined this behavior in a corporate management context. This research finds that when investors focus on short-term earnings results, corporate managers react to this myopic view by managing for the short term. In the resulting equilibrium, the managers artificially boost short-term earnings and the market rationally anticipates this behavior.

Subsequent research has focused specifically on asset management, beginning with the mutual fund industry. This research finds similar outcomes. Investors chase performance. They pour funds into recent sensational performers, yet often fail to exit underperformers at the same pace. Managers respond to this behavior by decreasing risk in scenarios in which additional outperformance would not help the fund as much as underperformance would 
hurt it and by increasing risk in opposite scenarios. That finding is worth repeating: The empirical evidence shows that when the incentives resulting from investor short-termism contradict what is actually best for the investors, managers tend to act in their own self-interest rather than abide by their fiduciary duty to those investors.

Analysis of investor short-termism in the hedge fund industry is sparse, in large part because of the opacity of the industry and the consequent lack of data for analysis. The research that has been performed demonstrates that investors in this industry also react strongly to short-term results. Outflows tend to respond to underperformance more quickly than inflows respond to outperformance, however, which is a striking difference between investor behavior in the hedge fund industry and in the mutual fund industry.

Systemic investor behavior can have sweeping effects on markets. It can make markets less efficient. The absolutist version of the efficient market hypothesis maintains that the existence of one rational trader in the market is sufficient to nullify the effect of many irrational ones; the one rational trader will simply counter any irrational trades from others and return the market to efficiency. Research has shown, however, that to the extent that the rational traders have limited capital or limited time horizons, such behavior would not be rational because the market could, in words attributed to John Maynard Keynes, remain irrational longer than the rational investor remained solvent.

Many asset managers, using Warren Buffett as a model, have taken steps to escape the effects of investor short-termism by setting up permanent capital vehicles resembling Buffett's Berkshire Hathaway. Berkshire Hathaway has provided its investors with a return that far outpaces the risk-free rate and has also decisively outperformed the S\&P 500 Index. It has, however, suffered its own ups and downs over time. For example, as the tech bubble expanded in the late 1990s, Berkshire Hathaway lost almost half its capital while the stock market gained 32\%. But in such cases, Buffett's firm was able to hold its positions until the market corrected because, unlike a mutual fund, Berkshire Hathaway is a firm with a fixed number of shares. As a result, anyone wanting to sell his or her shares has to sell them to another investor rather than back to the issuer.

Management firms that have followed suit include Pine River Capital Management, which set up two publicly traded REITs, and many hedge funds, such as Moore Capital, Greenlight, Paulson, SAC, and Third Point Management. All of them have created reinsurance companies in which the hedge funds manage the assets.

\section{The Banking Industry and the Financial Crisis of $\mathbf{2 0 0 8}$}

The banking industry contains its own share of principal-agent problems, many of which were highlighted by the financial crisis of 2008 . The 
complexity of the banking industry creates an environment that is ripe for potential incentive conflicts. In the run-up to the financial crisis, bank employees often faced conflicts between the incentives created by their compensation contracts and their duty to the shareholders of their companies. The government certainly faced tension between its duty to represent taxpayer interests and its stance of not interfering with private industry. And the bailouts themselves forged a new principal-agent relationship between bank managers and the taxpayers whose money was used to stabilize their institutions. The complex relationships among the various parties, combined with the density of relevant information in each transaction, provided a fertile breeding ground for principal-agent issues. Furthermore, the amount of money involved amplified each individual's incentives significantly, making those incentives more difficult to ignore.

Many bank employees faced conflicts between their own incentives and their responsibility to their banks' shareholders. Traders, who take on risk on behalf of bank shareholders, often have unlimited upside to their bonuses, whereas the shareholders participate equally in upside and downside outcomes. This situation motivates traders to take on much more risk than is optimal for the shareholders. During the financial crisis, this misalignment became apparent, with many traders receiving enormous bonuses, even though their trades brought down the very banks for which they worked.

The research is more forgiving in its evaluation of bank managers than traders. Like traders, some bank executives received large bonuses over time frames that included periods of loss that wiped out a decade's worth of prior earnings. However, the research that examines the relationship between the banks' losses and the structural alignment of their managers' incentives is mixed. Some of the evidence suggests that the banks that did better during the crisis had management compensation structures that were better aligned with the interests of shareholders. Other research demonstrates that banks whose managers had incentives closely aligned with shareholder interests actually performed worse. A third stream of research has shown that bank CEOs did not move to liquidate their personal holdings before the crisis, which demonstrates that they did not anticipate the losses.

Overall, the literature in this area seems to conclude that, for better or worse, bank managers were as unaware as the rest of the market that the crisis was going to materialize. It also shows, however, that bank managers' personal incentives probably played a role in the banks' behavior under the Troubled Asset Relief Program (TARP). Banks whose CEO compensation was above the TARP limit were more likely to reject TARP, and this likelihood increased significantly as manager compensation rose.

Through TARP and other policies, the US government also served as a major player in the financial crisis, creating principal-agent problems with its 
own actions. (Striking similarities exist between the US financial crisis and that of Japan in the late 1990s.) First, the US government needed to ensure that the structure of the Capital Purchase Program motivated the "right" banks to apply for the preferred stock capital injections offered under the program. Second, the US Treasury needed to ensure that it approved the banks whose financial distress costs were the highest. Research shows that the government succeeded in both endeavors.

Some of the government's actions, however, have been called into question. The insertion into the banks' capital structures of a government-owned layer just above common equity meant that only one layer of capital needed to fail before regulators would have to seize bank assets to protect the taxpayers. The market perceived this change as an increase in risk, and banks with small common equity cushions suffered, in terms of stock market performance, relative to banks with large cushions.

The government's behavior regarding Fannie Mae and Freddie Mac has also been questioned. In 2008, the Federal Housing Finance Authority (FHFA), acting in its authority as conservator of these entities, struck a deal with the US Treasury that stabilized Fannie and Freddie in exchange for preferred stock amounting to $\$ 1$ billion. About four years later, the FHFA and the Treasury signed an amendment to that agreement providing the Treasury with a full sweep of Fannie's and Freddie's earnings in the future as repayment for the taxpayers' investment in the two firms.

Consequently, several principal-agent problems have been alleged to exist. The first involves a conflict of interest for the FHFA, which has a fiduciary duty to act on behalf of Fannie and Freddie shareholders in its role as conservator but also has a duty to act on behalf of the taxpayers in its role as part of the government. The second principal-agent issue pertains to an alleged violation of the Administrative Procedure Act and involves a conflict of interest within the government between its duty to act on behalf of the taxpayers as owners of Fannie and Freddie and its duty to administer the Housing and Economic Recovery Act by guiding Fannie and Freddie toward private ownership. The third issue alleges an improper use of the law of takings and involves a conflict between the government's role as agent of the taxpayers and its duty to provide just compensation when it forcibly removes private property.

The research has also illuminated potential principal-agent problems in the role of rating agencies. These agencies' revenue streams are generally a function of how many ratings they provide, and this system creates an incentive to sacrifice accuracy for speed. Furthermore, the oligopolistic nature of the ratings market enables issuers to engage in "ratings shopping"-that is, having their securities rated by the agency that will provide the highest rating. This behavior, in turn, gives the agencies an incentive to skew their 
ratings upward. In addition, the repeat-customer nature of the business has resulted in many issuers' receiving advice from the agencies on structuring the very securities that will later be rated-a practice that has been likened to an auditor auditing his or her own work.

\section{Conclusion}

Organizations such as CFA Institute have developed codes of ethics to guide finance professionals and to set expectations for ethical behavior and professional conduct. Reflection upon such behavior, and on how successful the industry as a whole has been in achieving its ethical goals, has rarely been more important than it is now. Financial products and relationships have become so complex and interwoven that discerning ethical actions from irresponsible behavior is significantly more difficult than it has been in the past. This development is demonstrated by the recent financial crisis, which threatened to bring down the entire financial system. Investors and the general public have noticed, as several recent surveys have shown, that trust both of and within the financial markets has reached frighteningly low levels.

Asset management compensation structures directly provide managers with incentives that, if misaligned with those of the investors, can lead to conflicts with the managers' fiduciary duty to those investors. The tendency of investors to focus on short-term performance can exacerbate this problem and provide managers with additional incentives that run counter to the investors' best interests. Consequently, many asset managers, wishing to avoid the misaligned incentives that investor short-termism can create, have sought sources of capital with long lockup periods and launched publicly traded entities to provide stable capital bases.

The banking industry contains its own share of potential incentive conflicts, many of which were highlighted by the recent financial crisis. Research on the compensation structures of senior bank executives is mixed, whereas most research on the incentives of the traders and others more directly involved in daily decisions points to these incentives as reasons for the increased risk on bank balance sheets. Several observers have also weighed in on changes the government must make to the current market environment to keep such problems from recurring. In addition, the literature offers considerable criticism of the way rating agencies are compensated. These researchers claim that the agencies' pay schemes motivate them to sacrifice accuracy for speed and to shade their ratings up to benefit their clients.

Who will act to solve these problems in the future? On their own, members of the financial profession are realizing that it is not enough to avoid conflicts or manage their own conflicts responsibly. A sustainable financial system requires a trustworthy reputation, not only for individuals but also 
for the industry. There has sometimes been a leadership void, but the recent financial crisis has prompted CFA Institute and other organizations to take a more active role in (1) aligning interests so that the economic benefits of finance can be realized and (2) improving corporate governance in the financial industry. By finding ways to cultivate an ethical culture in the finance industry, we can together shape a better future for finance.

The complete monograph can be found at http://www.cfapubs.org/toc/rflr/2014/9/1.

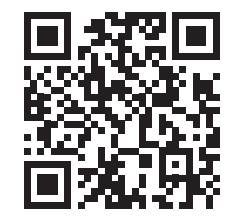

Use your smartphone to scan the $\mathrm{QR}$ code to go straight to the webpage. 


\title{
Investment Professionals and Fiduciary Duties (a summary)
}

\author{
Marianne M. Jennings \\ Published 2014 by the CFA Institute Research Foundation \\ Summary prepared by Marianne M. Jennings
}

The distinction between the role of a broker and the role of an investment adviser may seem clear to those within the profession but not necessarily to their clients. Investment advisers are classified as fiduciaries who must act in the best interests of their clients. Brokers are not fiduciaries. That distinction survived and enjoyed regulatory allowances until the 1980s. However, over the past 30 years, the distinction between these two roles has become increasingly blurred. This blurring of the roles-in addition to investor losses and increased regulatory activity - has led the profession and the investment industry to a crossroads in terms of the nature of the roles investment professionals play and the standards to which they will be held.

\section{The Nature of the Business and the Role of Participants: Current Status}

Whether a fiduciary standard should be applied to all of the various roles investment professionals play in the financial markets has been and continues to be a legal, regulatory, and ethical debate. For example, analysts play diverse roles in the financial markets. Analysts who work on the sell side of brokerage firms provide information related to investment banking services that their employers provide to issuers. Their employers appreciate any optimism their employee analysts can muster about clients' securities. (The clients are the issuers, not the purchasers, of the securities.) These sell-side analysts also provide fairness opinions in mergers, another type of transaction in which analysts' employers have an interest in seeing that the merger succeeds.

Analysts play other roles as well, including purchasing and selling securities for their individual clients, which places them somewhere on the investment adviser/broker continuum. Still other analysts provide investment management services for large funds, including mutual and pension funds, which also places them somewhere along the continuum. And there is inherent tension between financial market participants and professionals because of different financial stakes. Clients want to maximize returns on their investments, employers want certain investment vehicles sold, professionals 
and their associations seek to foster trust and respect from both investors and the public, and markets seek stability and transparency.

\section{The History of Market Advisers and Their Regulation}

The Securities Exchange Act of 1934 covers the secondary trading markets, including brokers and stock exchanges, but the expansion of investment vehicles to include mutual funds, closed-end funds, and investment trusts created a regulatory void that was filled by the passage of the Investment Company Act of 1940. Accompanying this act was the Investment Advisers Act of 1940, which established a regulatory structure for monitoring advisers with the goal of protecting investors through asset protections as well as bans against self-dealing.

These two acts provided a structure for registering investment advisers as well as broker/dealers and the foundation for a code of ethics for professionals beyond statutory requirements. However, broker/dealers were specifically exempted from the fiduciary standards of the Investment Advisers Act if certain conditions were satisfied, including certain statutory requirements as well as self-regulation and adoption of ethics codes.

By 1939, investment professionals and investment firms had created the National Association of Securities Dealers (NASD), charged with the protection of investors through standards for and enforcement of open and honest conduct of its members under the SEC's oversight. These types of self-regulatory organizations (SROs) assumed a role in the protection of investors in various ways, beyond just their codes of ethics, including licensing, certification, and recovery funds. The NASD evolved into the Financial Industry Regulatory Authority (FINRA), which is a self-regulatory body. Broker/dealers who do business with the public are required to be registered with FINRA.

\section{The Blurring of the Distinction between Broker/Dealers and Investment Advisers}

Under the framework initially established through federal regulation and adopted codes of ethics, there was a clear differentiation of duties between broker/dealers and investment advisers. Advisers were those who, directly or through publications, advised others-either for compensation or as part of their business. Originally, a broker was defined as a "person engaged in the business of [executing trades] in securities for the account of others," 1 and a dealer was defined as a "person engaged in the business of buying and selling securities for his own account."

No contractual relationship exists between broker/dealers and clients in which there is ongoing monitoring of the client's funds and investments. A

\footnotetext{
${ }^{1}$ Securities Exchange Act of 1934, 15 USC § 78c, § 3(a)(4)(A) (1934).

${ }^{2}$ Securities Exchange Act of 1934, 15 USC § 78c, § 3(a)(5)(A) (1934).
} 
broker/dealer may make a recommendation on a particular security, but once the transaction is complete, the broker/dealer receives no further compensation. However, this statutory distinction has all but disappeared in practice. During the 1990s, broker/dealers began offering fee-based accounts to their customers. Because of pushback from broker/dealers, the SEC allowed the new broker/dealer fee structure and continued the exemption as long as the broker/dealers were offering advice that was only "incidental" to brokerage services. The rule was challenged as an ultra vires act (an act that the SEC did not have the legal authority to undertake), so the SEC developed its threepart analysis as a liability standard for advisers:

- Advisory status would be determined on a case-by-case basis.

- Charging different commissions for different brokerage services would not automatically mean that a broker/dealer was charging "special compensation," thus resulting in investment adviser status.

- A broker/dealer who exercised investment discretion beyond limited or temporary discretion would be considered an investment adviser and subject to the Investment Advisers Act.

The court interpretation of the exemption is that if there is a commission payment arrangement, the exemption applies, regardless of the type of advice or even the pressure that the broker/dealer might be under to sell certain stocks.

The exemptions began to evolve over time. For example, if a broker/dealer sold clients certain investment vehicles that entitled him to higher commissions than if he had sold the clients similar vehicles sponsored by firms other than his own, the resulting conflict of interest required more disclosure.

The shifting structure of investment firms added to the increasingly confusing line between fiduciary and nonfiduciary conduct that the courts were developing. In the 1940s, broker/dealers and investment advisers were separate and did not overlap. Today, physically, brokers, dealers, and advisers often operate under the same investment firm roof. There is an additional complication in the broker/dealer versus investment adviser status: Broker/ dealers use stockbrokers to interact with clients. As agents of their principals, stockbrokers owe a duty of loyalty to their principal, the broker/dealer. That duty to the principal trumps any duties owed to the clients placing orders.

As these operational and physical changes were taking place, a body of judicial precedent and SRO standards was evolving. When the hearings related to the Dodd-Frank bill (the Wall Street Reform and Consumer Protection Act of 2010) were taking place, the role and definition of a fiduciary became a focal point for the public as well as for regulatory attention. The emotionally charged hearings on whether a broker/dealer owed a fiduciary 
duty to its clients resulted in a directive in the statute to the SEC to study the issues in and obtain public opinions about broker/dealers being subject to a fiduciary duty when advising retail and institutional investors.

\section{Present Status of Fiduciary Standards}

The study by the $\mathrm{SEC}^{3}$ came to the conclusion that the broker/dealer does and should fulfill a fiduciary role, a conclusion based on the following findings:

- Investors are confused by the roles played by investment advisers and broker/dealers.

- Many investors are also confused by the standards of care that apply to investment advisers and broker/dealers.

- It is burdensome for investors to have to parse legal language to determine what kind of advice they are entitled to from investment advisers and broker/dealers.

- Uniformity of duties on the part of investment advisers and broker/dealers is necessary to prevent investor confusion.

\section{Economic Impact of a Change to a Fiduciary Standard}

Requiring broker/dealers to be subject to a fiduciary standard imposes additional costs on them as well as on their firms. Because there are additional duties, risk, and liability, one of the consequences is higher costs for retail investors; broker/ dealers can raise their commissions to cover the costs of the additional risks.

There will also be investor costs because of the generic impact of universal protections for buyers/investors. When investors have a healthy dose of skepticism, they tend to do their own research and make better decisions. Reliance on fiduciary standards may lessen the instinctive self-protective work that allows buyers/investors to screen out bad products.

Another potential cost is that compliance with disclosure requirements would reduce the speed with which broker/dealers could complete transactions. Still another is the loss of freedom to tailor contracts and offerings according to needs, with risk varying among the types of clients.

\section{Can the Regulatory Course Be Changed?}

Despite the costs of imposing fiduciary duty standards on broker/dealers—as well as the study results indicating that this action may not accomplish legislators' and regulators' goals of improving retail investors' advice from broker/dealers, knowledge, and decision making-it seems that we are inexorably marching in

${ }^{3}$ SEC, "Study on Investment Advisers and Broker-Dealers as Required by Section 913 of the Dodd-Frank Wall Street Reform and Consumer Protection Act” (January 2011). 
that direction. However, every business statute or regulation that presently exists began as an ethical dilemma. There is a regulatory cycle with phases through which an issue progresses from the time of its appearance as an ethical issue to its eventual fate as a subject of legislation, regulation, or adjudication.

When ethical issues arise and are not yet subject to statutory resolution, businesses and industries enjoy wide latitude regarding the issue. Some members of the industry will seize the unregulated moment a bit too aggressively. There is a reliance on legalities in a field that demands trust and a standard higher than simply what the law allows. The aggressive seizure of a loophole by some market participants means that other, more ethical participants will be at a disadvantage.

This misunderstanding about the ethical rules of the game in the initial stage of the cycle inevitably results in the harms and losses that come from asymmetrical information distribution. "How was I to know that you held positions in these securities that are different from mine?" "How could I have known that you were putting together the pools of mortgages?" When the harm and investment losses come, those who trusted seize the moral high ground and take their case to the public. The public is sympathetic because their assumptions about markets often match those of the individuals who experienced the losses. Armed not with loopholes in the Investment Advisers Act but with the simple standards of ethics and fiduciary duty, they are able to make their case against the investment managers and achieve increased regulation. They appeal to the emotions that naturally arise when an individual is betrayed by a trusted party. The resulting sympathy for the victim and outrage at the perpetrator drive the regulatory cycle.

The public calls for reform because it has lost faith in a company's or industry's willingness to change its behavior, practices, or products. If voluntary reform is not forthcoming, the issue moves into the litigation, legislative, or regulatory (administrative agency) stage.

In the case of broker/dealer responsibilities to clients and calls for the imposition of fiduciary duties, the 2008 market collapse moved the issue very quickly. Suddenly, the issue of fiduciary duty, one that had occupied the halls of academia since the 1940s, was being covered in USA Today. The public suddenly had an interest in the nuances of investment advisers versus broker/ dealers and how loopholes worked to the advantage of investment firms in terms of required disclosures.

Presently, the industry appears to be somewhat defiant about the SEC decision to expand the application of the fiduciary standard to broker/dealers; many in the industry seem to believe that the cycle can still be halted. The hard truth is that industry concerns about market impact and costs to investors are accurate. Another hard truth is that additional disclosure and liability standards do not always produce better outcomes for investors. 
However, some strategies can be used in the final phase of the regulatory cycle that give the industry a chance to shape the form of this regulation. Broker/dealers and investment advisers should take part in shaping the regulation to minimize the economic consequences and harms to investors that were outlined earlier.

The key to the efficacy of these strategies, in terms of shaping the eventual content of the regulations on fiduciary duty, is for the industry to acknowledge that there are issues that require behavior modification and then offer solutions to address those issues, thus limiting overly broad regulatory strokes that may not focus on these critical issues. Acknowledgment of bad behavior in the industry is a means of establishing credibility for a seat at the regulatory formation table.

The focus of the industry should be on precision in definitions. For example, the careful delineation of the type of investor to be protected as well as the duties of broker/dealers will be helpful to both the industry and investors. Another possibility is simply defining the exact duties of care and loyalty that should be required. The "universal standard of care" is a possibility-one that covers prudence, conflicts, disclosure, the avoidance of misleading information, and more precision in the "best interests of the client" standard.

Self-regulation is another tool that can be used to offer reassurance during the regulatory phases. Continuing to adopt higher standards than the legal minimums is a means of negotiation during the final regulatory phase.

The goal for the industry at this stage in the long history of "fiduciary standards" should be to provide investors with a picture of investment professionals: This is who we are, this is what we do, and this is what we will not do. If those components are not present because of weak existing SRO standards or enforcement, then the focus should be on higher standards and adding rigor to existing self-enforcement proceedings. A candid evaluation of industry conduct, discipline, and rules is necessary.

$* * * * * *$

The complete monograph can be found at http://www.cfapubs.org/toc/rflr/2014/9/2.

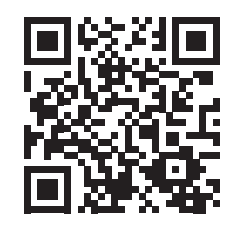

Use your smartphone to scan the $\mathrm{QR}$ code to go straight to the webpage. 


\title{
Islamic Finance: Ethics, Concepts, Practice (a summary)
}

\author{
Usman Hayat, CFA, and Adeel Malik, PhD \\ Published 2014 by The CFA Institute Research Foundation \\ Summary prepared by Usman Hayat, CFA, and Adeel Malik, PhD
}

Islamic economic thought and finance are rooted in Islamic ethics, but their ideals and means are not exclusive to Islam. The principles of Islamic finance emphasize market-based risk sharing of financing that promotes asset and enterprise, deploys finance in the service of the real economy, and facilitates redistribution of wealth and opportunity. Modern Islamic financial practices, however, promote legal forms over economic substance, creating an expectations gap between theory and practice. In the wake of the global financial crisis of 2007-2008, the ideas underlying Islamic finance appeal to people who are concerned with the broad impact of finance on society.

\section{Many Debates about Islamic Finance}

Widely regarded as one of the fastest-growing segments of global finance, Islamic finance is the subject of many debates. Should religion have anything to do with finance? Can guidance about economics and finance be derived from Islam? What exactly is meant by prohibition of riba in Islam? Is equity financing superior to debt financing for long-term economic prosperity? Is the Islamic financial sector "Islamic" only in form, not in substance? Can such a thing as an Islamic commercial bank operate within the prevalent monetary and banking system? Will following the legal minimum of Islamic commercial jurisprudence by commercial financial institutions lead to fulfillment of the higher objectives of Islam?

These questions are but a sample of the debates regarding Islamic finance.

Such debates in this field give rise to many opinions, but it is a matter of fact rather than opinion that Islamic finance is the most prominent faithbased finance in the world today. One way to describe it is "finance that is consistent with Islamic teachings." Specifically, Islamic finance must avoid "sin" (i.e., prohibited) businesses; it must also abide by the Islamic prohibitions of riba and excessive gharar, which are generally understood to include, respectively, lending money at interest and sale of risk. ${ }^{1}$ Consider a simple

\footnotetext{
${ }^{1}$ We are of the view that translating the Arabic terms riba and gharar tends to cause more confusion than clarity. Therefore, throughout the literature review, we do not use any English translation of these terms.
} 
application: Islamic finance is not to be used to finance a brewery because the underlying activity - consumption of alcohol-is prohibited by Islam. Similarly, the money cannot be used for lending money at interest (as is the case in a conventional bond) or sale of risk (as in conventional derivatives and proprietary insurance) because of the prohibitions of riba and excessive gharar. An idea strongly associated with Islamic finance is that the financiers and those being financed need to assume the risk associated with business outcomes or ownership of an asset. Where risk is to be managed through insurance, it should be managed through a mutual risk-sharing arrangement. The prohibitions, therefore, promote risk sharing and applying assets and enterprise in the real economy, facilitating redistribution of wealth and opportunity and social solidarity.

\section{About the Literature Review}

Using literature published since the year 2000, this review introduces the subject of Islamic finance and outlines the context to the literature; discusses Islamic economic thought and highlights its pertinence for Islamic finance; explains the major elements of Islamic law and prohibitions concerning Islamic finance; addresses the use of "nominate" contracts and promises (or legally binding unilateral undertakings) in structuring Islamic finance products; touches on regulatory issues; spells out governance and social responsibility; discusses the political economy in which Islamic finance operates; elaborates on the "form versus substance" debate; and summarizes the findings of some of the empirical studies while offering concluding thoughts.

We touch on a few of these elements in this summary.

\section{Origins}

The ideas and practice of Islamic finance are not necessarily exclusive to Islam but have a wider appeal. Many non-Muslims participate in Islamic finance in various capacities, including as entrepreneurs, business partners, professionals, investors, customers, and thought leaders.

Modern Islamic finance practices-unlike Islam, which dates back to the 7 th century-are a 20th-century phenomenon. Islamic finance includes banking, capital markets, and insurance in various countries of the world, but in terms of its assets, the industry largely consists of commercial banking in countries with Muslim-majority populations. And Islamic finance is growing rapidly. Industry reports estimate the total assets in Islamic finance at about $\$ 1.5$ trillion as of 2013 and observe a double-digit compound growth rate in recent years, with similar growth forecast for the foreseeable future. 


\section{Common Misconceptions}

A host of misconceptions are associated with Islamic finance. For example, Muslims and Islamic finance are monoliths that conform to generalizations; modern Islamic finance is a relatively old and mature industry; most Muslims understand the theory and practice of Islamic finance and follow it in their financial lives; Islamic finance enjoys active government support in most Muslim-majority countries; the assets of Islamic finance tend to be greater than those of conventional finance in most Muslim-majority countries; Shari'a is the governing law in all countries with a Muslim majority, and Islamic finance transactions are governed only by Shari'a; Islamic finance is not open to non-Muslims; Islamic finance is mainly about charitable rather than commercial activities; Islamic finance involves illegal activities, such as money laundering and even the financing of terrorism; prohibited riba is the same as interest; Islamic finance is recession proof and immune from unethical practices; and the Islamic finance industry is widely believed to be Islamic in form and in substance.

\section{Islamic Economic Thought}

Islamic economic thought (or Islamic economics) is the cornerstone for the theory and practice of Islamic finance. The Islamic worldview places moral checks on the economic behavior of believers, but ideas associated with a market economy and capitalism are not necessarily inconsistent with Islamic economic thought. Islamic economics places special emphasis on social justice and espouses a strong preference for risk sharing, profit sharing, and equitylike modes of financing. Debt is viewed with suspicion.

The salient instruments for redistribution are profit-sharing contracts, a social welfare tax (zakab), charitable giving (sadaqa), charitable endowment (waqf), interest-free loans (qard hasan), and inheritance.

Islamic economic thought espouses ideals that are not always followed in practice. Economic decision makers in Muslim-majority countries, for example, have shown little interest in translating the underlying vision of Islamic finance into reality.

\section{Islamic Finance in Practice}

Islamic financial transactions in banking, capital markets, and insurance are structured through nominate contracts and promises as found in Islamic commercial jurisprudence.

Commercial Banking. On the liability side, Islamic commercial banks offer various types of accounts. Some types are safekeeping accounts without any prospect of return on the deposit. The bank, however, may offer return 
in the form of a discretionary gift. There are also investment accounts, which may be restricted or unrestricted in their scope. These investment accounts tend to be based on a contract similar to investment management.

On the asset side, Islamic commercial banks use these nominate contracts (alone or combined with other types of contracts) to offer various other financing arrangements. The most common contract in Islamic financial practice is a trust sale, also referred to as banking murabaha. In this arrangement, the financier buys a good and sells it to the customer on installment credit, in which arrangement the credit price is more than the spot price. By owning the asset, the financier is seen as assuming the risk associated with asset ownership. From the perspective of Islamic commercial jurisprudence, however, clear evidence must be available that legal title and possession of the asset (whether actual or constructive) are actually transferred to the financier before the good is sold to the customer.

Capital Markets. In discussing Islamic finance in the capital markets, we cover equity funds and sukuk.

Equity funds. The majority of Islamic funds are long-only equity funds. Generally, Islamic equity funds follow exclusionary screening to avoid companies whose primary business is in conflict with Islamic jurisprudence. The greatest impact of exclusionary screening is usually the removal for consideration of the conventional financial and insurance sectors, which are sometimes the largest sectors in stock exchanges.

After the initial screening based on a company's primary business, further exclusionary screens are applied to avoid businesses with an unacceptably high level of impermissible income (usually 5\%). Businesses with high interest-bearing debt (usually more than a third of market capitalization or total assets) are also excluded. Dividend income attributable to impermissible income is donated to charity, although the same is not attempted for capital gains, which remains a subject of debate. The screening process is generally negative, although positive alignment is also deployed in some cases (e.g., investing in an Islamic sustainability index).

Sukuk. Islamic investment certificates (sukuk) should represent ownership in real assets, whereas conventional bonds are about ownership of financial debt. Sukuk can be structured in a variety of ways, even when using the same underlying nominate contract. A common structure underlying sukuk is a lease (ijara). The originator sells an asset to a special-purpose vehicle (SPV), which is the sukuk issuer, and receives the initial cash flow. The SPV leases the asset back to the originator, which pays rentals to the SPV. Upon expiration of the agreed term, the originator, calling on the purchase and sale undertakings previously signed, buys back the asset at a fixed price. The rent of the asset may comprise the principal, a rate of return, and any charges incurred for maintaining the asset. The originator thus acts as a seller, lessee, obligor, and servicing agent. 
Islamic Insurance (Takaful). Instead of selling risk, which goes against the prohibition of excessive gharar, in takaful (solidarity, mutual obligation), risk is to be shared through mutuality. The majority of takaful providers are set up as hybrids of mutual and proprietary insurance, in which a for-profit shareholder-owned company operates the mutual takaful pool. Insurance coverage is provided by the takaful participants to each other through the participants' takaful fund, and the takaful operator manages the underwriting and investment on behalf of the takaful participants. In general, agency (wakala) contracts and investment management (mudaraba) contracts are used between the participants and the operator for, respectively, underwriting and investment management. The takaful operator earns a fee on the underwriting contributions and shares part of the profits from investments. Constraints apply to the investments of takaful funds, which are usually made in equities, sukuk, real estate, and profit-sharing investment accounts with Islamic banks.

\section{Form vs. Substance Debate}

A frequent criticism of the contemporary practice of Islamic finance is that it is "Islamic" in legal form but conventional in economic substance. The form versus substance debate signifies the gap between the principles of Islamic finance and its practice. Although conventional interest-bearing monetary loans are described as un-Islamic, they are mimicked in Islamic finance, eliminating any substantive difference between the two-especially in commercial banking, which is the largest segment of the Islamic finance industry. Because critics find Islamic and conventional finance unusually similar where they were expected to be different as a result of Islamic prohibitions, they question the Islamic credentials and socioeconomic value addition of Islamic finance.

\section{Empirical Studies and Concluding Thoughts}

Comparative empirical studies of the performance of Islamic finance are complicated by the similarities in the underlying substances of conventional and Islamic finance, especially in Islamic commercial banking. Those who consider Islamic finance a success tend to focus on growth and profitability; those who consider it a failure typically question its Islamic authenticity and social and economic value.

Islamic finance also generally operates within a political economy that is predicated on preserving rather than changing the status quo. Where a government has actively supported Islamic finance, the system retains an uncomfortable similarity to conventional finance.

Some have questioned the direction of Islamic finance by asking why it is concerned with morally regulating the operations of individual business 
people rather than promoting economic growth at the macro level and distributing resources in accordance with Islamic principles of social justice.

Nevertheless, in the wake of the global financial crisis of 2007-2008, the ideas underpinning Islamic finance might appeal to those who aspire to a relatively restrained financial system and are concerned about the broad impact of finance on society.

The complete book can be found at http://www.cfapubs.org/toc/rflr/2014/9/3.

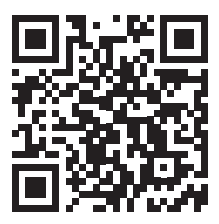

Use your smartphone to scan the $\mathrm{QR}$ code to go straight to the webpage. 


\section{Saving DB Pension Plans: What It Will Take, and Why (a summary)}

\section{Barton Waring \\ Presentation given at CFA Society Los Angeles, 3 June 2014, with webcast published 3 June 2014 Summary prepared by Laurence B. Siegel}

Many defined benefit (DB) pension plans have become seriously underfunded in recent years, which has led to decisions by plan sponsors to close the plans to new entrants and, in some cases, to close the plans entirely, giving beneficiaries a lump sum and replacing the plan with a defined contribution (DC) plan. Meanwhile, essentially all newly established plans are DC plans. The disappearance of the DB plan is a great loss to beneficiaries and to society. It has been said that the worst DB plan is better than the best DC plan, and allowing for a bit of hyperbole, we generally agree. This article focuses on public plans.

The decline of DB plans can be traced to the failure of plan sponsors, their actuaries, consultants, and others to understand the basic economics of pensions. A DB pension promise is, simply, a portfolio of deferred annuities. The steps involved in funding such a promise are as follows: project the future benefit payments, discount them to present value, make payments into the plan to pay for them, keep track of progress, and adjust the contributions and investment strategy to reflect market and actuarial surprises.

The key step is discounting. The higher the discount rate used, the lower the apparent liability. Because pension benefits must be paid, the riskless rate (US T-bond rate) is the correct discount rate. Public pension plans, however, typically use the expected return on pension assets as the discount rate, despite the fact that this rate is totally irrelevant and gives much too low a present value for the liability. (Corporate plans, more sensibly, use a bond yield, but not the riskless bond yield, so that rate is still incorrect. It is, however, much better than the expected return on overall assets, which typically include a large weight in equities.)

Pension economics can be understood only by using economic - that is, market value-balance sheets and market measures of rates of return, both realized and expected. Pensions are currently managed, however, with the use of bookvalue concepts because accountants and actuaries favor these concepts. Pension managers must use market-value concepts and measures if they are to be successful. The accounting will always follow the economics in the long run.

Let's see what happens when we use an expected return assumption that is too high as the discount rate. The S\&P 500 Index delivered only a $0.55 \%$ per 
year compound average return for the 12 years between 2000 and 2011; that is, a dollar grew to only $\$ 1.07$. (This amount is nominal; the real, inflationadjusted return was, in fact, negative over this period.) A much higher expected-return assumption of $8 \%$ - commonly used by pension managerswould have caused a dollar to grow to $\$ 2.52$ over a 12 -year period. So, at the end of 2011, the real assets earned in the market were worth only $42 \%$ of what was expected! Stated another way, pension managers budgeted and made contributions as though the plan were earning $8 \%$ when it was really earning $0.55 \%$. If a household ran its savings plan this way, it would be in the poorhouse. No wonder there is a pension crisis.

Figure 1 compares the annual contributions needed, given the same investment returns, from the economic (risk-free rate) method with the contributions

Figure 1. Annual Contributions under Both Methods

Contribution (\$)

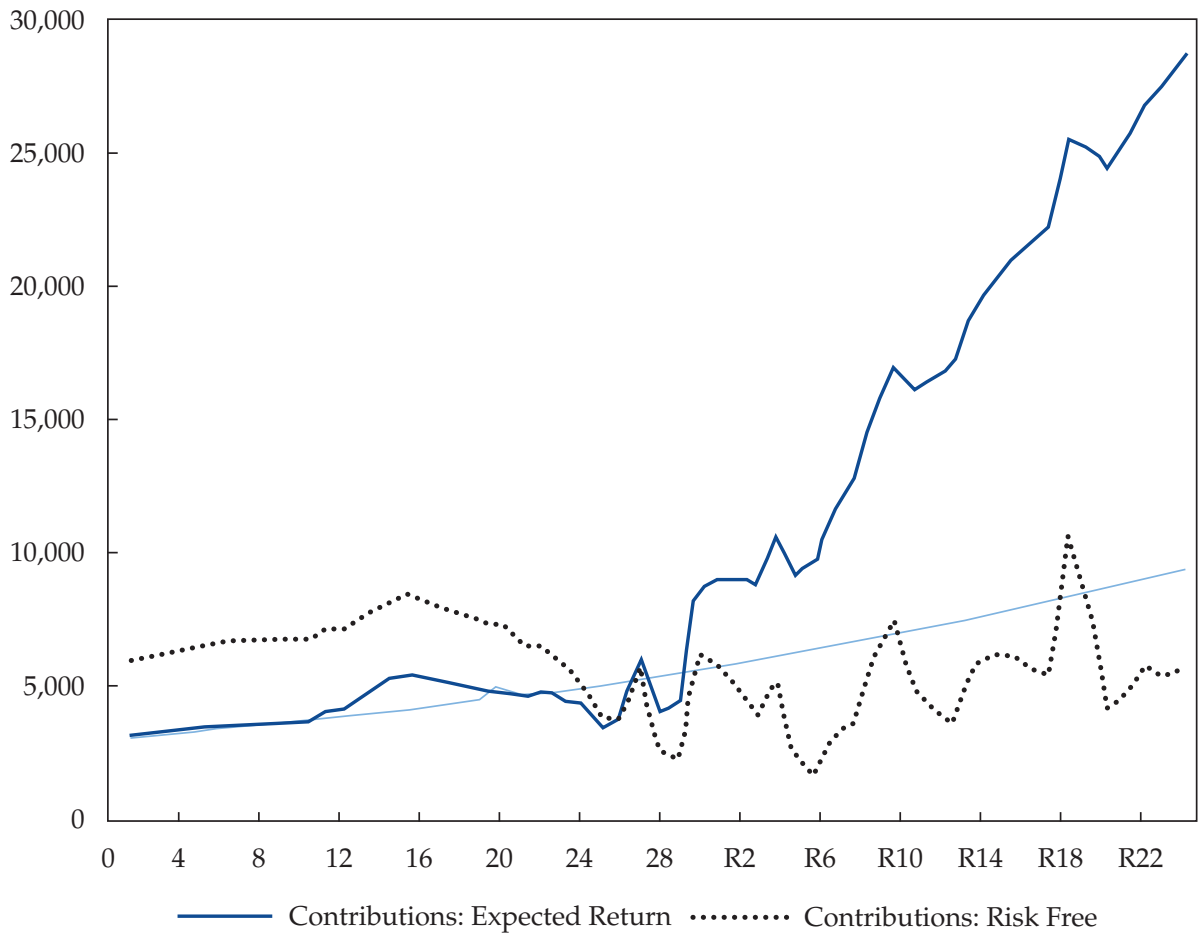

Lifetime Normal Cost

Notes: To construct this example, a hypothetical time period was used when market returns averaged less than $8 \%$ per year. The horizontal axis shows 30 years of work followed by 25 years of retirement; the retirement years are indicated by an $\mathrm{R}$. 
needed under the conventional (expected return on assets) method. The thick solid line shows contributions to the pension plan calculated by using the expected return on assets (in this case, an $8 \%$ return) as the discount rate for the liability. Contributions are lower than when the economic method is used at the beginning of the period, but they are extremely volatile and extremely high in later years. The dotted line representing the economic method shows contributions calculated by using the risk-free rate as the discount rate. These contributions, although higher at the beginning, are much lower than the thick solid line in later years (lower on average) and much more stable.

Who will pay the huge contributions represented by the blue line? Unless a massive bailout by taxpayers occurs, the answer is "the beneficiaries," by receiving only cents on the dollar. This result is morally and economically unacceptable.

Employees of corporations that defaulted on their pension plans when they went bankrupt (sometimes because of pension contributions!) are able to collect partial benefits from the Pension Benefit Guaranty Corporation, a US government agency that charges corporate pension plans an insurance premium. Public plans have no such insurance coverage. Moreover, there is typically no money to make up the deficit: bad markets also mean low tax revenues.

In summary, a program of "tough love" is required to save underfunded public DB plans. Providers of the plans need to

- renegotiate benefits on the basis of knowing the true cost of secure benefits; that is, a dollar of secure benefits costs twice what the plan has assumed in the past;

- in the future, regard contribution promises as hard obligations-no avoidance-that are enforceable as debt payments; amortization should be minimal;

- NOT terminate the DB plan! It is far more efficient at providing retirement income than any DC plan.

$* * * * * *$

Video of the entire presentation can be found at https://vimeo.com/97883297.

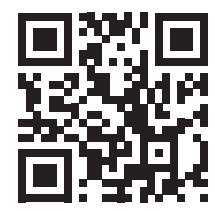

Use your smartphone to scan the QR code to go straight to the webpage. 


\title{
Manager Selection (a summary)
}

\author{
Scott D. Stewart, CFA \\ Presentation at the 13th Annual Research for the \\ Practitioner Workshop, 4 May 2014 \\ Summary prepared by Scott D. Stewart, CFA
}

\section{The Importance of Manager Selection}

Manager selection is a critical step in implementing any investment program. Even though investment objectives may be finalized and targets for asset class weights set, an investment plan is not productive until it is implemented through the purchase or sale of securities, properties, commodities, and derivatives. In most cases, investors choose portfolio managers to determine the most appropriate instruments in which to place assets. Investors hire portfolio managers to act as their agents, and portfolio managers are trusted to perform to the best of their abilities and in the investors' best interests.

Investors must practice due diligence when selecting index managers or active portfolio managers. Investors want managers who are highly skilled, diligent, and persistent, and they also want managers whose interests are aligned with their own. But investors need to do more than identify skillful managers; they need to determine the appropriate weights to assign to those managers.

The goal of this book is to help investors improve their practice of manager selection. It highlights the influence that investment policy statements have on manager selection and proposes techniques for hiring active, indexed, and alternative managers. Strategies for setting portfolio manager weights are also reviewed, along with techniques for monitoring current managers. A large part of the book is devoted to providing an in-depth look at the value of quantitative and qualitative methods for successful manager selection. Special issues for financial advisers and individual investors are also addressed. The book concludes with a summary of key recommendations.

\section{How Manager Selection Fits within the Investment Process}

An investment policy statement (IPS) has important implications for manager selection. It should include a description of the client or investor, the overall mission, and the goals for investing. It should also document the investment objectives that the investor considers most relevant in determining appropriate managers and setting relationship expectations. 
Investors' views, horizons, sizes, and experiences influence the formulation of an IPS and, in turn, affect the selection process. For example, investors' liquidity needs, quality preferences, and risk guidelines will constrain the search for appropriate managers. Investors should carefully consider the implications for manager selection when formulating their IPS.

\section{Identifying Skilled Active Managers}

If we gather the returns of all portfolios-both indexed and active, institutional and retail — and weight them by their values, the result (before fees and transaction costs) will equal the return on the market. If all portfolios are not identical in composition, some will exhibit performance that is higher than the market and some will exhibit lower performance. Empirical evidence supports these conclusions, but the estimates must be prepared with care. For example, many portfolios are not publicly observable.

The arithmetic of active management illustrates that some managers will outperform or underperform market averages. The efficient market hypothesis questions whether any manager has the ability to create alpha. Given a large sample of managers, it should not be difficult to find some with performance records that appear to reflect statistically significant alphas. But this approach ignores the fact that the best performing managers are cherry-picked from the market sample. Based on sophisticated tests, it appears that skillful managers do exist, but the number of managers that demonstrate skill with high statistical confidence appears to be small.

This book details the techniques investors use for selecting active managers and reports on their effectiveness. For example, there is evidence that alphas persist at least for a short time. There is also evidence that superior scores on aptitude tests are positively correlated with superior investment performance. But there is no guaranteed method to identify managers who will outperform in the future. In fact, evidence shows that both retail and institutional investors on average do not profit from their manager hiring and firing processes.

\section{Index Fund Investing}

The goal of investing in index funds is to replicate the performance of a prespecified equity or fixed-income benchmark. Index managers provide investors with inexpensive access to returns on the market. The term "passive management" is sometimes used to describe indexing, but it does not reflect the skill that index fund managers need to have to deliver accurate results, which in many cases are defined by deviations of a few basis points relative to published indices. This book reports that index fund performance, net of fees, shows evidence of persistence; therefore, investors can improve their selection process by reviewing managers' historical record of benchmark tracking. 


\section{Asset Allocation Policy and Its Implications for Manager Selection}

The asset allocation process entails setting optimal weights of broad classes of securities, such as stocks and bonds, within a portfolio. The more complex a set of assets is, the more effort will be required for manager selection. For example, selecting a large-cap equity index fund is a relatively straightforward process, whereas private equity investing requires a thorough and lengthy process of due diligence of managers and partnerships. This book recommends that investors consider the implications for the manager selection process when formulating their strategic asset allocation policies.

\section{Setting Weights for Active and Index Managers}

The manager selection process involves conducting due diligence, identifying the most skillful managers, and determining the proportion of assets each manager should control. Investors set manager weights to meet strategic asset allocation goals, capture alpha potential of active managers, and access the tracking abilities of index managers.

Determining optimal mixes of portfolio managers is dependent on investors' expectations for alphas, their attitudes toward active risk, and managers' risk exposures. Investors may seek optimal trade-offs between active return and active risk or, alternatively, maximize active return while holding active risk to an acceptable level. This optimization problem can be expressed as a mathematical model and is illustrated in the book by using a case study and a Microsoft Excel template that investors can use to set manager weights.

\section{The Dynamics of Manager Selection: Performance Analysis, Monitoring, and Fee Incentives}

Investors' horizons, market characteristics, and manager alphas all vary over time. Ideally, an IPS should specify prompts, independent of performance, for conducting special reviews of current managers. Investment professionals should avoid hiring managers at the top of their performance cycle and should use several different tools to evaluate their managers over time. These include tools to estimate alphas, compute performance attribution, and evaluate fee structures, including performance-based schedules. These issues are reviewed, and an Excel template is included to explain how to estimate manager alphas.

\section{Research Findings on Manager Selection}

Finance research literature explores whether active managers earn statistically significant alphas, whether alphas persist once found, and whether investors profit from hiring and terminating investment managers. This book contains a chapter that summarizes research on portfolio managers and entrepreneurs 
(who share traits with portfolio managers) and outlines manager selection techniques that have been shown to be successful in the past.

\section{Issues for Financial Advisers}

Individual investors, including high-net-worth and retirement investors, face more challenges than institutional investors in successful manager selection. They are subject to higher expenses, including taxes, and have less time to focus on investing. Individual investors are often less sophisticated and less experienced than institutional investors and, as a result, often seek the support of financial advisers. Several approaches are proposed for financial advisers to improve their manager selection processes.

\section{Manager Selection for Global Markets and Alternative Asset Classes}

The manager selection process is more complex for global investing than for domestic investing, and the same holds true for alternative versus traditional investing. This book reviews research evidence on active global equity, private equity, and hedge fund investments and proposes techniques for selecting managers for these asset classes.

\section{Key Recommendations and Best Practices}

The final chapter of the book summarizes key recommendations for manager selection, including advice shared by experienced investors, pension consultants, and money managers.

$* * * * * *$

The complete book can be found at http://www.cfapubs.org/toc/rf/2013/2013/4.

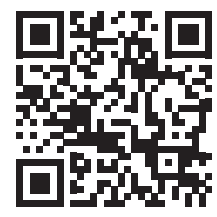

Use your smartphone to scan the $\mathrm{QR}$ code to go straight to the webpage. 


\title{
Asset Allocation with Macroeconomic Foundations: The Risk Factor Approach (a summary)
}

\author{
Vasant Naik and Sébastien Page, CFA \\ Presentation at the 13th Annual Research for the \\ Practitioner Workshop, 4 May 2014 \\ Summary prepared by Vasant Naik and Sébastien Page, CFA
}

The goal of this presentation was to provide the missing link between macroeconomic analysis and risk factor-based quantitative analysis for asset allocation. For the past 60 years, portfolio theory has received both praise and criticism. To balance return against risk at the portfolio level is a worthy objective, but the models we use to achieve this objective may be misleading because they are often divorced from macroeconomics. In this presentation, we argued that pension plans, foundations, endowments, and individuals should pay close attention to each of the following improvements to the traditional approach to asset allocation.

- Formulating forward-looking macro views. Investors have long recognized that naive extrapolation of past data can lead to disastrous investment outcomes. Too often, quantitative models ignore the current state of the world. For example, most data samples include periods of declining rates and moderate inflation. In contrast, over the next few years, given current Federal Reserve policy and unsustainable levels of debt-to-GDP ratios, inflation may creep up and rates may rise. Similarly, although developed markets' sovereign bonds have historically been viewed as safe havens, downgrade risk may cause them to have higher-than-historical correlations with risky assets in the future.

In general, in the wake of the financial crisis, investors must recognize the importance of combining quantitative models with a macroeconomic view of the world. Historical data analysis can be useful (after all, we don't have future data) but only to the extent that it helps formulate a view about the future. Some investors may not have strong active views, but nonetheless, they need to account for current macroeconomic conditions.

- Diversifying across risk factors. The recent financial crisis reinforced the notion that asset class returns are driven by common risk factors. An 
asset class can be viewed as a bundle of factor exposures. In this presentation, we showed how risk factor analysis can be used to translate macroeconomic views into expected risks and returns across asset classes. Ultimately, we showed that risk factors provide a flexible language with which investors can express their forward-looking views and diversify their portfolios accordingly.

Importantly, the risk factor approach to asset allocation is helpful because traditional asset classes often mask true diversification. To show US equities, global equities, small-capitalization and large-capitalization equities, high-yield debt, private equity, and real estate as separate colors on a pie chart creates the illusion of diversification. But, as has often been demonstrated, equity risk contributes most of the risk in portfolios that seek to diversify across these asset classes. This presentation offered a transparent step-by-step tutorial on how to link macroeconomic views to optimal risk factor-based asset allocation.

- Adopting a dynamic approach. The traditional approach to asset allocation focuses on a three-to-five-year horizon. Typically, investors optimize their asset mixes, set tolerance bands (to minimize deviations from the target asset allocations), and more or less close their eyes until the end of the horizon. Unfortunately, significant events often occur along the way. The number of times Earth completes a revolution around the sun has nothing to do with how abruptly valuations, and thereby expected returns and risks, may change.

In this presentation, we suggested that a macroeconomic approach incorporating expectations about the future and optimal asset allocations must take into account both the cyclical and secular horizons. For this purpose, investors with a rigid governance process and no clear mandate to follow a dynamic process can outsource the process to external multiasset managers, through asset allocation mandates, strategic partnerships-often referred to as "external CIO" (chief investment officer) mandates-or both.

- Focusing on tail risks. Unforeseen market crises are often referred to as "tail risk events" because of the way they appear in the "normal," bell-shaped curve often used to illustrate market outcomes. The most likely outcomes lie in the center of the curve; the unforeseen, less-likely events that can wreak havoc on a portfolio are plotted at either end —or tail—of the curve. Standard deviation is the measure of how spread out the numbers are in the bell curve-that is, how volatile the returns are expected to be. Much 
has been said of the failure of standard deviation, however, as a measure of exposure to large losses in financial markets. For example, two asset allocations with identical expected return and volatility may have very different exposures to loss. Yet, investors still routinely compare asset allocations in terms of Sharpe ratios, which rely on standard deviation as the measure of risk. We contend that exposure to loss is what matters.

Although our forthcoming monograph for the CFA Institute Research Foundation covers a wide range of topics related to these themes, in this presentation, we focused on tactical asset allocation with macro views and the stock-bond correlation.

\section{Tactical Asset Allocation with Macro Views}

To the extent investors can produce fairly accurate macroeconomic forecasts, they may be able to use the risk-factor framework to outperform their peers and benchmarks. In this section of the presentation, we demonstrated, based on the approach to tactical asset allocation with macroeconomic views in Mattu, Naik, Matheos, Devarajan, and Sharif (2012), how to apply macro insights in practice.

Suppose an investor (or investment organization) formulates forecasts of the likely path of the global economy over the cyclical horizon. These evolving macroeconomic forecasts - of growth rates of GDP, unemployment rates, and other economic indicators around the world — can be summarized in a set of probabilities for various economic outcomes defined in terms of global growth and inflation.

Another important input into the process is the forecast of returns on the major investment choices in specific economic scenarios. Sector-specific forecasts may come from teams that specialize in particular market segments, and an investment committee determines the relevant macroeconomic scenarios, evaluates macroeconomic risks, and vets the scenario return forecasts. In this way, the process takes inputs from both a top-down and a bottom-up view.

Such an investment process can be integrated with a quantitative methodology for optimal portfolio construction. First, we specify the probabilities of broad macroeconomic scenarios. Next, we combine these inputs with estimates of returns in various scenarios and with historical volatilities and correlations.

Our central premise is that the return forecasts for markets in various scenarios are best understood as averages conditioned on particular scenarios rather than as the only possible returns in those scenarios. In other words, a given scenario represents a range of possible but related outcomes. Although real growth and inflation shocks may be the most important drivers of 
returns, other asset-specific factors may determine market outcomes-for example, housing finance-related policy variables in agency mortgages, geopolitical supply shocks in oil markets, or central bank activity in currencies.

To estimate risk, we recognize the two sources of uncertainty: the uncertainty about which scenario will be realized and the uncertainty around conditional means of returns within each scenario. We estimate within-scenario risk from historical data, whereas we derive the uncertainty caused by scenario shifts from variations in return forecasts among the scenarios. In this way, our methodology combines rich historical data on return volatilities and correlations with forward-looking macroeconomic views.

Finally, we use portfolio optimization to combine all the inputs and arrive at optimal overlays. In such optimizations, common practice is to constrain the solution to remain within reasonable bounds and to ensure that the procedure does not attempt to leverage small differences in returns by taking large long-short positions in highly correlated assets. Liquidity-based constraints that require that the solution move only gradually from existing positions that are considered illiquid are also applied.

\section{The Stock-Bond Correlation}

The correlation between stocks and bonds is one of the most important inputs to the asset allocation decision. However, that correlation is difficult to estimate reliably and can change drastically with macroeconomic conditions. From 1927 to 2012, based on data from Ibbotson (downloaded from Haver Analytics) and calculated by calendar year from monthly data, the correlation between the S\&P 500 Index and long-term US Treasury bonds (T-bonds) has changed sign 29 times and has ranged from $-93 \%$ to $+86 \%$.

Johnson, Naik, Page, Pedersen, and Sapra (2013; hereafter JNPPS) developed an econometric model that helps explain the historical relationship between US equities and T-bonds. Although several factors influence the stock-bond correlation, our analysis reveals the importance of four key macroeconomic factors: real interest rates, inflation, unemployment, and growth. We show that stocks and bonds have the same sign sensitivity to the real (inflation-adjusted) policy rate and to inflation whereas their sensitivities to growth and unemployment have opposite signs. Hence, depending on which factors dominate, the correlation can be either positive or negative.

Importantly, the JNPPS model incorporates both short-run (cyclical) and long-run dynamics, which enables us to estimate correlations for various 
horizons. Cyclical and long-run correlations may differ for a variety of reasons. For example,

- In the short run, stocks and bonds tend to respond in opposite directions to fluctuations in investors' risk appetite. During flight-to-safety episodes, we observe the familiar negative correlation. In the long run, however, secular trends in growth, inflation, and interest rates may have similar effects on stock and bond returns, inducing a positive correlation.

- The negative beta between stocks and inflation may be less pronounced over long horizons than short horizons as dividends gradually catch up with inflation. (In general, the negative beta between stocks and inflation is considered a puzzle; it tends to occur at very high inflation levels. Because there is a broad consensus that price stability should be one of the key objectives of a central bank, high inflation in a country is probably the result of deep macroeconomic imbalances.)

- Starting valuation levels may play an important role. Consider the environment in early May 2013, when valuations in bonds (and perhaps stocks) may have been stretched by the Federal Reserve's balance sheet activities. If central banks act in such a way that both asset classes are overvalued, joint mean reversion in valuation should lead to both assets underperforming together, even if business-cycle factors generate a negative correlation. The speed of this mean reversion will also, in general, influence the magnitude of the correlation.

Our framework addresses the term structure of correlation through an error correction model. This approach accounts for both long- and short-run dynamics. The long-run dynamics are estimated between the levels of the macroeconomic factors as well as valuations for stocks and bonds; the shortrun dynamics capture the impact of quarterly changes in the macroeconomic factors as well as transitory deviations from the long-run relationships (the "error correction" component).

Our econometric model also addresses the current environment and generates forecasts of stock-bond correlations over horizons ranging from one quarter to two years. Since the financial crisis of 2008, the short-run correlation has been very negative. An important question our framework seeks to answer is whether higher interest rates or rising inflation in the future may make this correlation less negative-perhaps even positive. In such a market regime, risk parity approaches that lever up bond positions to hedge equity holdings could be challenged. 
JNPPS expect a correlation of roughly $-25 \%$ at the quarterly frequency. Hence, we expect bonds to continue to diversify equity risk, albeit less than in the recent past. We expect this diversification effect to be diminished over long horizons. In our central scenario, however, the correlation is not expected to rise above zero, even over a two-year horizon.

The sensitivity analysis carried out by JNPPS reveals some tail risks. For example, if inflation volatility increases by $50 \%$ of its current level and other factors remain the same, the correlation in two-year returns could rise to as much as $+20 \%$.

\section{Takeaways}

Throughout this presentation, we focused on the link between macroeconomic forces and risk factor returns. This type of analysis requires mapping asset classes to their exposures to equity risk, interest rate risk, spread risk, and so on. Once this mapping is complete, investors can analyze (and seek to predict) the performance of financial assets in various macroeconomic scenarios.

Based on our framework, we showed how to enhance a (hypothetical) fundamental macroeconomic investment process with robust quantitative analysis. We emphasized the importance of risk regimes and showed how to combine regime-based qualitative views with empirical data analysis. Such an approach to parameter estimation and portfolio optimization helps soften the edges of forward-looking qualitative views, which tend to be extreme almost by definition.

Then, we modeled the link between macroeconomic variables on the stock-bond correlation at various time horizons. Without a low or negative stock-bond correlation, diversifying portfolios away from the equity risk factor can be extremely challenging, as evidenced by the presence of indirect equity exposures in credit, commodities, and alternative investments. We showed that depending on which macroeconomic variable dominates, investors can expect widely different stock-bond correlations. Rising rates and inflation surprises typically lead to more positive correlations, whereas growth and unemployment surprises lead to more negative correlations-especially during flight-to-safety events.

\section{References}

Johnson, Nicholas, Vasant Naik, Sébastien Page, Niels Pedersen, and Steve Sapra. 2014. "The Stock-Bond Correlation.” Journal of Investment Strategies, vol. 4 , no. 1 (December): 1-16. 
Mattu, Ravi, Vasant Naik, Peter Matheos, Mukundan Devarajan, and Masoud Sharif. 2012. "Tactical Asset Allocation with Macro Views: From Macro Forecasts to Optimal Portfolio Construction.” PIMCO Quantitative Research and Analytics (October): www.pimco.com. 


\section{James R. Vertin Award}

The James R. Vertin Award is presented periodically to recognize individuals who have produced a body of research notable for its relevance and enduring value to investment professionals. This award was established in 1996 to honor James R. Vertin, CFA, for his outstanding leadership in promoting excellence and relevancy in research and education.

\section{Vertin Award Winner}

\section{Kenneth R. French}

Kenneth R. French is the Roth Family Distinguished Professor of Finance at the Tuck School of Business at Dartmouth College. He is an expert on the behavior of security prices and investment strategies. He and co-author Eugene F. Fama are well known for their research into the value effect and the three-factor model, including articles such as "The Cross-Section of Expected Stock Returns" and "Common Risk Factors in the Returns on Stocks and Bonds." His recent research focuses on tests of asset pricing, the tradeoff between risk and return in domestic and international financial markets, and the relationship between capital structure and firm value.

Professor French is a Research Associate at the National Bureau of Economic Research, an Advisory Editor of the Journal of Financial Economics, a former Associate Editor of the Journal of Finance and the Review of Financial Studies, and a former President of the American Finance Association. He is also a Fellow of the American Finance Association and the American Academy of Arts and Sciences and a member of the Smile Train's Board of Governors and the International Rescue Committee's Board of Directors.

Before joining Dartmouth, Professor French was on the faculty of MIT's Sloan School of Management, the Yale School of Management, and the University of Chicago Booth School of Business. Professor French received his $\mathrm{PhD}$ in finance from the University of Rochester in 1983 . He also earned an MS and an MBA from the University of Rochester and a BS from Lehigh University. 


\section{Past Vertin Award Winners}

2013 Richard C. Grinold

2013 Ronald N. Kahn

2012 Elroy Dimson

2010 Roger Clarke

2009 Robert Shiller

2008 Keith Ambachtsheer

2007 Campbell R. Harvey

2006 Clifford S. Asness

2005 Andrew W. Lo

2004 Edwin J. Elton
2004 Martin Gruber

2003 Barr Rosenberg 2002 William L. Fouse, CFA

2001 Rex A. Sinquefield

2001 Roger G. Ibbotson

2000 Peter L. Bernstein

1998 Martin L. Leibowitz

1997 Jack L. Treynor

1996 William F. Sharpe 


\title{
Research Foundation Leadership Circle
}

The Research Foundation Leadership Circle honors investment professionals whose outstanding commitment and contributions have benefited the Research Foundation over an extended period of time. The Research Foundation is honored to recognize the following members of the Leadership Circle:

\author{
Gary Brinson, CFA \\ George Noyes, CFA \\ Frank Reilly, CFA \\ Fred Speece, CFA \\ Walter Stern, CFA \\ James R. Vertin, CFA
}




\title{
Recent Publications from the Research Foundation Archive
}

\section{3}

\section{Monographs}

\author{
Manager Selection (December) \\ Scott D. Stewart, CFA
}

Manager selection is a critical step in implementing any investment program. Investors hire portfolio managers to act as their agents, and portfolio managers are then expected to perform to the best of their abilities and in the investors' best interests. Investors must practice due diligence when selecting portfolio managers. They need to not only identify skillful managers but also determine the appropriate weights to assign to those managers. This book is designed to help investors improve their ability to select managers. Achieving this goal includes reviewing techniques for hiring active, indexed, and alternative managers; highlighting strategies for setting portfolio manager weights and monitoring current managers; and considering the value of quantitative and qualitative methods for successful manager selection.

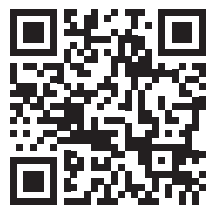

Fundamentals of Futures and Options (November) Roger G. Clarke, Harindra de Silva, CFA, and Steven Thorley, CFA

Derivative securities and markets have experienced tremendous worldwide growth since 1970. But even so, they are not always well understood. To remedy this situation, the authors explain the link between options and futures and the underlying security or index from which they ultimately derive their value. Pricing and hedging relationships of futures contracts, option characteristics and strategies, and option pricing and hedging relationships are also addressed. To further assist the reader, the authors include exercises to reinforce the concepts as well as a glossary. The result is an updated look at options and futures that can benefit many of us.

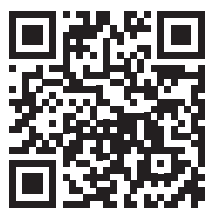


Life Annuities: An Optimal Product for Retirement Income (May) Moshe A. Milevsky

This book provides a summary of research on life annuities, longevity insurance, and their role in the "optimal" retirement portfolio. It starts with an overview of institutional aspects, moves on to discuss valuation issues, and concludes with a comprehensive review of the scholarly literature.

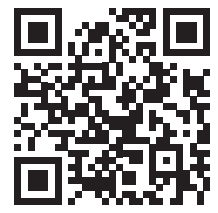

\section{Literature Reviews}

“The Evolution of Asset/Liability Management" (September) Ronald J. Ryan, CFA

This review tracks the development of asset/liability management from its roots in liability management outsourcing to its most recent interpretation as a broad liability-driven investing strategy.

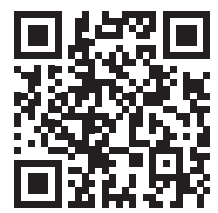

"Ethics and Financial Markets: The Role of the Analyst" (September) Marianne M. Jennings

The ethical issues that financial professionals face are no different from the ethical issues in any profession-or, indeed, the day-to-day dilemmas we all face. These issues are readily resolved through the use of three simple questions: Does this violate the law? Is this honest? What if I were on the other side? These three basic ethical standards are often complicated, extrapolated, rationalized, refined, and confused as those in the financial markets grapple with what they believe are more complex ethical issues today than in the past. But as this review shows, the ethical issues in the financial markets today are no different from those that managers of money and assets, financial advisers, and analysts have faced over the centuries.

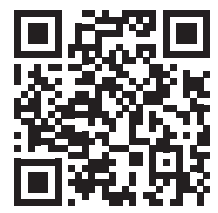




\section{2}

\section{Monographs}

\section{A Nerw Look at Currency Investing (December)}

\section{Momtchil Pojarliev, CFA, and Richard M. Levich}

The authors of this book examine the rationale for investing in currency. They highlight several features of currency returns that make currency an attractive asset class for institutional investors. Using style factors to model currency returns provides a natural way to decompose returns into alpha and beta components. They find that several established currency trading strategies (variants of carry, trend-following, and value strategies) produce consistent returns that can be proxied as style or risk factors and have the nature of beta returns. Then, using two datasets of returns of actual currency hedge funds, they find that some currency managers produce true alpha. Finally, they find that adding to an institutional investor's portfolio even a small amount of currency exposure-particularly to alpha generators-can make a meaningful positive impact on the portfolio's performance.

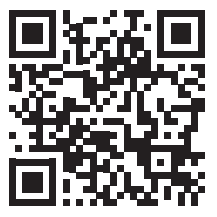

\section{Life-Cycle Investing: Financial Education and Consumer Protection (November)} Edited by Zvi Bodie, Laurence B. Siegel, and Lisa Stanton, CFA

Third in the series of Boston University-sponsored conferences titled "The Future of Life-Cycle Saving and Investing," the May 2011 conference again brought together academic researchers, educators, advisers, and regulators. This time, we analyzed the gaps in consumers' current financial knowledge, how those gaps might be narrowed through financial education programs, and how consumer protection regarding financial products might be strengthened-with a focus on low- and middle-income households. Although there was general agreement that consumers of financial products and services make many costly mistakes, there was also considerable disagreement about relying primarily on consumer financial education programs to correct those mistakes.

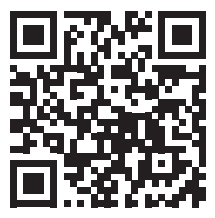


Fund Management: An Emotional Finance Perspective (August)

David Tuckett and Richard J. Taffler

To increase understanding of the real world of the fund manager, the authors apply principles from emotional finance. They report their findings from analysing in-depth interviews of 52 traditional and quantitativeoriented equity managers. In particular, they examine the importance of storytelling in the managers' ability to act in the face of uncertainty. The nature of the fund managers' job requires them to cope with emotions that, particularly if denied, can threaten to overwhelm their thinking.

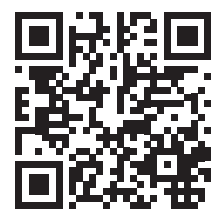

Expected Returns on Major Asset Classes (June)

Antti Ilmanen

Can the art and science of investment management be reduced to a set of patterns that markets generally follow, in apparent violation of the efficient market hypothesis? Can investors reasonably expect to make money from the knowledge of these patterns, even after they have not only been identified but also widely exploited? Although one's first guess might be that the answers to these questions are no, at least sometimes, the answer is yes.

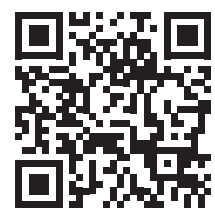

\section{Literature Reviews}

“The New Field of Liquidity and Financial Frictions" (June)

David Adler

Illiquidity and other financial frictions are critical to financial markets and the overall economy. This literature review provides a synopsis of academic research in this rapidly developing specialty field, offering insights into 
liquidity and asset pricing, systemic risk, macro frictions, and new models of the causes of a liquidity crisis.

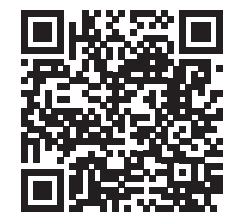

"Equity Valuation and Inflation: A Review" (January)

Stephen E. Wilcox, CFA

In theory, equity returns should be neutral to inflation. In practice, however, evidence of such behavior in the short run has been difficult to come by. This literature review provides a synopsis of much of the academic and practitioner research regarding the effects of inflation on equity prices.

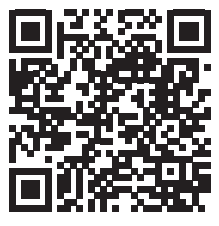

\section{1}

\section{Monographs}

Rethinking the Equity Risk Premium (December)

Edited by P. Brett Hammond, Jr., Martin L. Leibowitz, and Laurence B. Siegel

In 2001, a small group of academics and practitioners met to discuss the equity risk premium (ERP). Ten years later, in 2011, a similar discussion took place, with participants writing up their thoughts for this volume. The result is a rich set of papers that practitioners may find useful in developing their own approach to the subject.

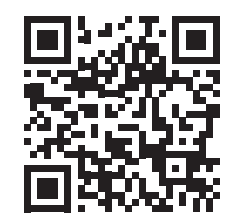


A Practical Guide to Risk Management (July)

Thomas S. Coleman

Managing risk is at the core of managing any financial organization. Risk measurement and quantitative tools are critical aids for supporting risk management, but quantitative tools alone are no substitute for judgment, wisdom, and knowledge. Managers within a financial organization must be, before anything else, risk managers in the true sense of managing the risks that the firm faces.

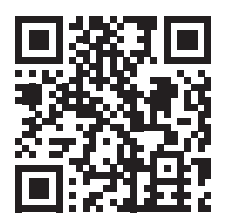

Frontier Market Equity Investing: Finding the Winners of the Future (May) Lawrence Speidell, CFA

Frontier markets represent a multitude of distinct cultures and can be overwhelming to investors. The author examines the many opportunities for investing that exist in frontier countries. He reviews the stock markets, the listed companies, the potential returns, and the diversification benefits. $\mathrm{He}$ also considers economic and political fundamentals.

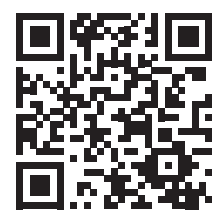

A Primer for Investment Trustees (January)

Jeffery V. Bailey, CFA, Jesse L. Phillips, CFA, and Thomas M. Richards, CFA

This "primer," written as if addressed to a new trustee for a university, is a comprehensive discussion of investment issues relevant not only to investment trustees but also to investment professionals who work with trustees. Taking an individual step-by-step through the process of responsible trusteeship, it offers a solid introduction to basic investment principles.

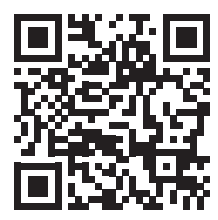




\section{Literature Reviews}

"Commodities as an Investment" (September)

Gerald R. Jensen, CFA, and Jeffrey M. Mercer

Interest in commodities has grown tremendously, partly because commodities are believed to provide direct exposure to unique factors and have special hedging characteristics. This review discusses the instruments that provide exposure to commodities, the measures and historical record of commodity investment performance, evidence about the benefits of strategic versus tactical commodity allocations, and recent developments in the market.

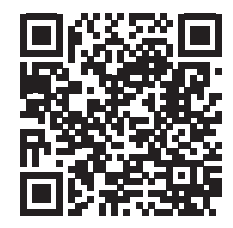

"Investment Issues in Emerging Markets: A Review" (February) C. Mitchell Conover, CFA, CIPM

Emerging markets have generated considerable interest among investors and academics. Although their returns are increasingly converging to those of the developed world because of integration and liberalization, they still provide benefits to a global portfolio. This review reflects the latest practitioner and academic work on emerging market investing.

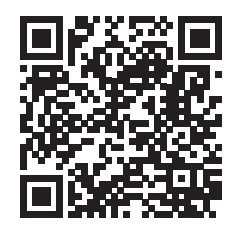




\section{RESEARCH FOUNDATION CONTRIBUTION FORM}

$\checkmark$ Yes, I want the Research Foundation to continue to fund innovative research that advances the investment management profession. Please accept my tax-deductible contribution at the following level:

Thought Leadership Circle. US $\$ 1,000,000$ or more

Named Endowment US $\$ 100,000$ to US\$999,999

Research Fellow US $\$ 10,000$ to US\$99,999

Contributing Donor US $\$ 1,000$ to US\$9,999

Friend Up to US\$999

I would like to donate \$

My check is enclosed (payable to the CFA Institute Research Foundation).

$\square$ I would like to donate appreciated securities (send me information).

$\square$ Please charge my donation to my credit card.

$\square$ VISA $\square$ MC $\square$ Amex $\square$ Diners

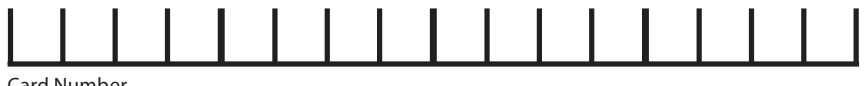

Card Number

Expiration Date

Name on card PLEASE PRINT

$\square$ Corporate Card

Personal Card

Signature

This is a pledge. Please bill me for my donation of $\$$

I would like recognition of my donation to be:

$\square$ Individual donation $\square$ Corporate donation $\square$ Different individual

PLEASE PRINT NAME OR COMPANY NAME AS YOU WOULD LIKE IT TO APPEAR

PLEASE PRINT $\square$ Mr. $\square$ Mrs. $\square$ Ms. MEMBER NUMBER

\begin{tabular}{lll}
\hline Last Name (Family Name) & First & Middle Initial
\end{tabular}

$\overline{\text { Title }}$

Address

\begin{tabular}{lll}
\hline City & State/Province & Country ZIP/Postal Code
\end{tabular}

Please mail this completed form with your contribution to:

The CFA Institute Research Foundation P.O. Box 2082

Charlottesville, VA 22902-2082 USA

For more on the CFA Institute Research Foundation, please visit www.cfainstitute.org/learning/foundation/Pages/index.aspx. 



\title{
The CFA Institute \\ Research Foundation \\ Board of Trustees \\ 2014-2015
}

Chair
John T. “JT" Grier, CFA
Virginia Retirement System
Jeffery V. Bailey, CFA
Target Corporation
Manu Bhaskaran, CFA
$\quad$ Centennial Asia Advisors Pte
Limited
Renee Kathleen-Doyle Blasky,
CFA
$\quad$ Vista Capital Limited
William Fung*
Aventura, FL
*Emeritus

Chair

ohn T. "JT" Grier, CFA

Diane Garnick

Clear Alternatives LLC

Beth Hamilton-Keen, CFA

Mawer Investment

Management Ltd.

Walter V. "Bud" Haslett, Jr., CFA

CFA Institute

George R. Hoguet, CFA, FRM

State Street Global Advisors

Joachim Klement, CFA

Wellershoff \& Partners Ltd.
Brian Singer, CFA

William Blair, Dynamic

Allocation Strategies

Paul Smith, CFA

CFA Institute

Wayne H. Wagner

Marina del Rey, CA

Arnold S. Wood*

Martingale Asset Management

Charles J. Yang, CFA

T\&D Asset Management

\section{Officers and Directors}

\author{
Executive Director \\ Walter V. "Bud" Haslett, Jr., CFA \\ CFA Institute \\ Gary P. Brinson Director of \\ Research \\ Laurence B. Siegel \\ Blue Moon Communications
}

Secretary

Tina Sapsara

CFA Institute

Treasurer

Kim Maynard

CFA Institute

\section{Research Foundation Review Board}

William J. Bernstein

Efficient Frontier Advisors

Stephen J. Brown

New York University

Elroy Dimson

London Business School

Stephen Figlewski

New York University

William N. Goetzmann

Yale School of Management

Elizabeth R. Hilpman

Barlow Partners, Inc.
Paul D. Kaplan, CFA

Morningstar, Inc.

Robert E. Kiernan III

Advanced Portfolio

Management

Andrew W. Lo

Massachusetts Institute of

Technology

Alan Marcus

Boston College

Paul O'Connell

FDO Partners
Krishna Ramaswamy

University of Pennsylvania

Andrew Rudd

Advisor Software, Inc.

Stephen Sexauer

Allianz Global Investors

Solutions

Lee R. Thomas

Pacific Investment

Management Company 
